\title{
Probing the subtropical lowermost stratosphere and the tropical upper troposphere and tropopause layer for inorganic bromine
}

\author{
Bodo Werner ${ }^{1}$, Jochen Stutz ${ }^{2}$, Max Spolaor ${ }^{2}$, Lisa Scalone ${ }^{1}$, Rasmus Raecke ${ }^{1}$, James Festa ${ }^{2}$, Santo Fedele Colosimo ${ }^{2}$, \\ Ross Cheung $^{2}$, Catalina Tsai ${ }^{2}$, Ryan Hossaini ${ }^{3}$, Martyn P. Chipperfield ${ }^{4}$, Giorgio S. Taverna ${ }^{4}$, Wuhu Feng ${ }^{5}$, \\ James W. Elkins ${ }^{6}$, David W. Fahey ${ }^{6}$, Ru-Shan Gao ${ }^{6}$, Erik J. Hintsa ${ }^{6,7}$, Troy D. Thornberry ${ }^{6,7}$, Free Lee Moore ${ }^{6,7}$, \\ Maria A. Navarro ${ }^{8}$, Elliot Atlas ${ }^{8}$, Bruce C. Daube ${ }^{9}$, Jasna Pittman ${ }^{9}$, Steve Wofsy ${ }^{9}$, and Klaus Pfeilsticker ${ }^{1}$ \\ ${ }^{1}$ Institute of Environmental Physics, University of Heidelberg, Heidelberg, Germany \\ ${ }^{2}$ Department of Atmospheric and Oceanic Science, University of California Los Angeles, Los Angeles, California, USA \\ ${ }^{3}$ Lancaster Environment Centre, University of Lancaster, Lancaster, UK \\ ${ }^{4}$ Institute for Climate and Atmospheric Science, School of Earth and Environment, University of Leeds, Leeds, UK \\ ${ }^{5}$ National Centre for Atmospheric Science, School of Earth and Environment, University of Leeds, Leeds, UK \\ ${ }^{6}$ NOAA Earth System Research Laboratory, Boulder, Colorado, USA \\ ${ }^{7}$ Cooperative Institute for Research in Environmental Sciences (CIRES), University of Colorado, Boulder, Colorado, USA \\ ${ }^{8}$ The Rosenstiel School of Marine and Atmospheric Science, University of Miami, Miami, Florida, USA \\ ${ }^{9}$ School of Engineering and Applied Sciences, Harvard University, Cambridge, Massachusetts, USA
}

Correspondence to: Klaus Pfeilsticker (klaus.pfeilsticker@iup.uni-heidelberg.de)

Received: 21 July 2016 - Published in Atmos. Chem. Phys. Discuss.: 19 September 2016

Revised: 20 December 2016 - Accepted: 5 January 2017 - Published: 25 January 2017

\begin{abstract}
We report measurements of $\mathrm{CH}_{4}$ (measured in situ by the Harvard University Picarro Cavity Ringdown Spectrometer (HUPCRS) and NOAA Unmanned Aircraft System Chromatograph for Atmospheric Trace Species (UCATS) instruments), $\mathrm{O}_{3}$ (measured in situ by the NOAA dual-beam ultraviolet (UV) photometer), $\mathrm{NO}_{2}, \mathrm{BrO}$ (remotely detected by spectroscopic UV-visible (UV-vis) limb observations; see the companion paper of Stutz et al., 2016), and of some key brominated source gases in whole-air samples of the Global Hawk Whole Air Sampler (GWAS) instrument within the subtropical lowermost stratosphere (LS) and the tropical upper troposphere (UT) and tropopause layer (TTL). The measurements were performed within the framework of the NASA-ATTREX (National Aeronautics and Space Administration - Airborne Tropical Tropopause Experiment) project from aboard the Global Hawk (GH) during six deployments over the eastern Pacific in early 2013. These measurements are compared with TOMCAT/SLIMCAT (Toulouse Off-line Model of Chemistry And Transport/Single Layer Isentropic Model of Chemistry And Transport) 3-D model simulations,
\end{abstract}

aiming at improvements of our understanding of the bromine budget and photochemistry in the LS, UT, and TTL.

Changes in local $\mathrm{O}_{3}$ (and $\mathrm{NO}_{2}$ and $\mathrm{BrO}$ ) due to transport processes are separated from photochemical processes in intercomparisons of measured and modeled $\mathrm{CH}_{4}$ and $\mathrm{O}_{3}$. After excellent agreement is achieved among measured and simulated $\mathrm{CH}_{4}$ and $\mathrm{O}_{3}$, measured and modeled $\left[\mathrm{NO}_{2}\right]$ are found to closely agree with $\leq 15 \mathrm{ppt}$ in the TTL (which is the detection limit) and within a typical range of 70 to $170 \mathrm{ppt}$ in the subtropical LS during the daytime. Measured [BrO] ranges between 3 and 9 ppt in the subtropical LS. In the TTL, [BrO] reaches $0.5 \pm 0.5 \mathrm{ppt}$ at the bottom $(150 \mathrm{hPa} / 355 \mathrm{~K} / 14 \mathrm{~km})$ and up to about $5 \mathrm{ppt}$ at the top $(70 \mathrm{hPa} / 425 \mathrm{~K} / 18.5 \mathrm{~km}$; see Fueglistaler et al., 2009 for the definition of the TTL used), in overall good agreement with the model simulations. Depending on the photochemical regime, the TOMCAT/SLIMCAT simulations tend to slightly underpredict measured $\mathrm{BrO}$ for large $\mathrm{BrO}$ concentrations, i.e., in the upper TTL and LS. The measured $\mathrm{BrO}$ and modeled $\mathrm{BrO} / \mathrm{Br}_{y}^{\text {inorg }}$ ratio is further used to calculate inorganic bromine, $\mathrm{Br}_{y}^{\text {inorg }}$. For the 
TTL (i.e., when $\left[\mathrm{CH}_{4}\right] \geq 1790 \mathrm{ppb}$ ), $\left[\mathrm{Br}_{y}^{\mathrm{inorg}}\right]$ is found to increase from a mean of $2.63 \pm 1.04 \mathrm{ppt}$ for potential temperatures $(\theta)$ in the range of $350-360 \mathrm{~K}$ to $5.11 \pm 1.57 \mathrm{ppt}$ for $\theta=390-400 \mathrm{~K}$, whereas in the subtropical LS (i.e., when $\left.\left[\mathrm{CH}_{4}\right] \leq 1790 \mathrm{ppb}\right)$, it reaches $7.66 \pm 2.95 \mathrm{ppt}$ for $\theta$ in the range of 390-400 K. Finally, for the eastern Pacific (170$90^{\circ} \mathrm{W}$ ), the TOMCAT/SLIMCAT simulations indicate a net loss of ozone of $-0.3 \mathrm{ppbv}^{-1} \mathrm{y}^{-1}$ at the base of the TTL $(\theta=355 \mathrm{~K})$ and a net production of $+1.8 \mathrm{ppbv} \mathrm{day}^{-1}$ in the upper part $(\theta=383 \mathrm{~K})$.

\section{Introduction}

At present, bromine is estimated to be responsible for roughly one-third of the photochemical loss in global stratospheric ozone (WMO, 2014). Past research has revealed that total stratospheric bromine $\left(\mathrm{Br}_{y}\right)$ has (in 2013) four major sources or contributions: (1) $\mathrm{CH}_{3} \mathrm{Br}$ which is emitted by natural and anthropogenic sources, with a present contribution of $6.9 \mathrm{ppt}$ to $\mathrm{Br}_{y}$, (2) four major halons $\left(\mathrm{CClBrF}_{2}\right.$ or halon1211; $\mathrm{CBrF}_{3}$ or halon-1301; $\mathrm{CBr}_{2} \mathrm{~F}_{2}$ or halon-1202; and $\mathrm{CBrF}_{2} \mathrm{CBrF}_{2}$ or halon-2402), all emitted from anthropogenic activities, with a present contribution of $8 \mathrm{ppt}$ to $\mathrm{Br}_{y}$; (3) socalled very short-lived species (VSLS); and (4) inorganic bromine transported into the upper troposphere, e.g., previously released from brominated VSLS and/or sea salt (e.g., Saiz-Lopez et al., 2004; Fernandez et al., 2014; Schmidt et al., 2016). This inorganic bromine is also partly transported into the stratosphere. Together sources 3 and 4 are assessed to contribute 5 (2-8) ppt to stratospheric bromine (WMO, 2014). Previous assessments of total $\mathrm{Br}_{y}$ and its trend revealed $\left[\mathrm{Br}_{y}\right]$ levels of $\approx 20 \mathrm{ppt}(16-23 \mathrm{ppt})$ in 2011, which has been decreasing at a rate of $-0.6 \% \mathrm{yr}^{-1}$ since the peak levels observed in 2000. This decline is consistent with the decrease in total organic bromine in the troposphere based on measurements of $\mathrm{CH}_{3} \mathrm{Br}$, and the halons (WMO, 2014).

Estimates of stratospheric $\mathrm{Br}_{y}$ essentially rely on two methods: first, the so-called organic $\left(\mathrm{Br}_{y}^{\text {org }}\right)$ method, where all bromine from organic source gases (SGs) found at the stratospheric entry level is summed (Wamsley et al., 1998; Pfeilsticker et al., 2000; Sturges et al., 2000; Brinckmann et al., 2012; Navarro et al., 2015). Second, total inorganic bromine $\left(\mathrm{Br}_{y}^{\text {inorg }}\right)$ is inferred from atmospheric measurements (e.g., performed from the ground, aircraft, high-flying balloons, or satellites) of the most abundant $\mathrm{Br}_{y}$ species, $\mathrm{BrO}$, assisted by a suitable correction for the $\mathrm{Br}_{y}^{\text {inorg }}$ partitioning inferred from photochemical modeling (e.g., Pfeilsticker et al., 2000; Richter et al., 2002; Van Roozendael et al., 2002; Sioris et al., 2006; Dorf et al., 2006a, 2008; Hendrick et al., 2007; Theys et al., 2009, 2011; Rozanov et al., 2011; Parrella et al., 2013; Stachnik et al., 2013). Further constraints on stratospheric $\mathrm{Br}_{y}$ (range 20-25 ppt) were obtained by satellite-borne measurements of $\mathrm{BrONO}_{2}$ in the mid-infrared (IR) spectral range at nighttime (Höpfner et al., 2009). While the organic method is rather precise for the measured species (accuracies are several tenths of a ppt), it suffers from the shortcoming of not accounting for any inorganic bromine (contribution 4) directly entering the stratosphere. Uncertainties in the inorganic method arise from uncertainties in measuring $\mathrm{BrO}$ as well as from modeling $\mathrm{Br}_{y}^{\text {inorg }}$ partitioning, of which the combined error amounts to $\pm(2.5-4)$ ppt, depending on the type of observation and probed photochemical regime.

Past in situ measurements of $\mathrm{Br}_{y}^{\mathrm{org}}$ were performed at different locations and seasons within the upper troposphere, the tropical tropopause layer (TTL), and stratosphere. In the present context the most important were measurements performed within the TTL (for the definition of TTL, see Fueglistaler et al., 2009) over the Pacific from where most of the stratospheric air is predicted to originate (e.g., Fueglistaler et al., 2009; Aschmann et al., 2009; Hossaini et al., 2012b; Ashfold et al., 2012; WMO, 2014; Orbe et al., 2015). These include the measurements (a) by Schauffler et al. (1993, 1998, 1999), who found [VSLS] = 1.3 ppt (contribution 3) at the tropical tropopause over the central Pacific (Hawaii) in 1996, (b) by Laube et al. (2008) and Brinckmann et al. (2012), with [VSLS] $=2.25 \pm 0.24 \mathrm{ppt}$ (range 1.4$4.6 \mathrm{ppt}$ ) and $[\mathrm{VSLS}]=1.35 \mathrm{ppt}$ (range $0.7-3.4 \mathrm{ppt}$ ) found within the TTL over northeastern Brazil in June 2005 and June 2008, respectively, and (c) most recently by Navarro et al. (2015), who found [VSLS] $=2.96 \pm 0.42$ and $3.27 \pm 0.49 \mathrm{ppt}$ at $17 \mathrm{~km}$ over the tropical eastern and western Pacific in 2013 and 2014, respectively. Information on contribution 3 was further corroborated by measurements performed in the upper tropical troposphere by Sala et al. (2014), who found [VSLS] $=3.72 \pm 0.60 \mathrm{ppt}$ in the upper tropical troposphere over Borneo in fall 2011, and by Wisher et al. (2014), who inferred [VSLS] $=3.4 \pm 1.5 \mathrm{ppt}$ for the CARIBIC (Civil Aircraft for the Regular Investigation for the Atmosphere Based on an Instrument Container) flights from Germany to Venezuela and Colombia during 20092011, Germany to South Africa during 2010 and 2011, and Germany to Thailand and Kuala Lumpur, Malaysia, during 2012 and 2013.

Supporting information on brominated VSLS concentrations typical of the boundary layer of the western Pacific came from measurements performed during the TransBrom ship cruise in October 2009 (median $2.23 \mathrm{ppt}$ and range from 1.45-4.14 ppt; Brinckmann et al., 2012) and the VSLS measurements made around Borneo during the SHIVA (Stratospheric Ozone: Halogen Impacts in a Varying Atmosphere) project (median $5.7 \mathrm{ppt}$ and range from 3.9 to $10.7 \mathrm{ppt}$; Sala et al., 2014). Corroborating model calculations to these field studies by (a) Tegtmeier et al. (2012) indicated that from the western Pacific on average only $0.4 \mathrm{ppt}$ and at a maximum up to $2.3 \mathrm{ppt}$ of the emitted VSLS bromine may reach the 
stratosphere, while (b) Liang et al. (2014) estimated that up to 8 ppt of VSLS bromine may enter the base of the TTL at $150 \mathrm{hPa}$, whereby the VSLS emissions from the tropical Indian Ocean, the tropical western Pacific, and off the Pacific coast of Mexico are suspected to be most relevant, and finally (c) the Community Atmosphere Model with Chemistry (CAM-Chem) modeling performed within the study of Navarro et al. (2015), which indicates that over the eastern and western Pacific contributions 3 and 4 (called [VSLS $+\mathrm{Br}_{y}^{\text {inorg }}$ ] in the study) amount to $6.20 \mathrm{ppt}$ (range 3.79$8.61 \mathrm{ppt}$ ) and 5.81 ppt (range 5.14-6.48 ppt), respectively.

Using the inorganic method, contributions 3 and 4 have been indirectly estimated from $\mathrm{BrO}$ measured at the ground, high-flying balloons, or satellites (e.g., Pfeilsticker et al., 2000; Richter et al., 2002; Van Roozendael et al., 2002; Sioris et al., 2006; Dorf et al., 2006b; Dorf et al., 2008; Hendrick et al., 2007; Theys et al., 2009; Theys et al., 2011; Rozanov et al., 2011; Parrella et al., 2013; Stachnik et al., 2013). All together these studies pointed to a range between 3 and 8 ppt with a mean of $6 \mathrm{ppt}$ for contributions 3 and 4 . The most direct information on contributions 3 and 4 come from the studies of Dorf et al. (2008), WMO (2011), and Brinckmann et al. (2012). They inferred $1.25 \pm 0.16 \mathrm{ppt}$ (very short lived - source gases, VSL-SGs, contribution 3) $+4.0 \pm 2.5 \mathrm{ppt}$ (product gases, PGs, contribution 4$)=5.25 \pm 2.5 \mathrm{ppt}$ (contributions 3 and 4) and $2.25 \pm 0.24 \mathrm{ppt}$ (VSL-SGs, contribution 3) $+1.68 \pm 2.5 \mathrm{ppt}$ (PGs, contribution 4) $=3.98 \pm 2.5 \mathrm{ppt}$ (contributions 3 and 4) from two balloon-borne soundings performed in the TTL and stratosphere over northeastern Brazil during the dry season in 2005 and 2008, respectively. The inferred bromine was thus often larger than [VSLS] inferred using the organic method (contribution 3), indicating that variable amounts of $\mathrm{Br}_{y}^{\text {inorg }}$ (i.e., several parts per trillion) are directly transported from the troposphere into the stratosphere (contribution 4).

Based on these findings, Saiz-Lopez et al. (2012) and Hossaini et al. (2015) provided evidence for the efficiency of short-lived halogens to influence climate through depletion of lower-stratospheric ozone (for contribution 3) but without explicitly considering the effect of inorganic bromine readily transported across the tropical tropopause (i.e., contribution 4). They concluded that VSLS bromine alone exerts a 3.6 times larger ozone radiative effect than is due to longlived halocarbons when normalized to their halogen content. Moreover the benefit for ozone and UV radiation due to the declining stratospheric chlorine and bromine since the implementation of the Montreal protocol was quantified in a recent study by Chipperfield et al. (2015). Finally, in a recent study Fernandez et al. (2016) pointed out that bromine from contribution 3 and 4 contributes about $14 \%$ to the formation of the present Antarctic ozone hole, in particular at its periphery. Further, they suggests a large influence of biogenic bromine on the future Antarctic ozone layer.
The present paper reports measurements of $\mathrm{BrO}$ (and $\mathrm{NO}_{2}$, $\mathrm{O}_{3}, \mathrm{CH}_{4}$, and the brominated source gases) made during the ATTREX (Airborne Tropical Tropopause Experiment) deployments of the NASA Global Hawk into the lowermost stratosphere (LS), upper troposphere (UT), and TTL of the eastern Pacific in early 2013. Corresponding data collected during the western Pacific deployments in early 2014 will be reported in a forthcoming paper, primarily since most of the 2014 measurements were performed under TTL cirrusaffected conditions, for which the interpretation of UVvisible (UV-vis) spectroscopic measurements is not straightforward (see below). The present paper further addresses the amount of inorganic bromine found in the TTL and its transport into the lowermost tropical stratosphere (contribution 4), together with the implications for ozone.

Our study accompanies those of Navarro et al. (2015) and Stutz et al. (2016). While Stutz et al. (2016) discusses the instrumental details and the methods employed to remotely measure $\mathrm{BrO}, \mathrm{NO}_{2}$, and $\mathrm{O}_{3}$, the study of Navarro et al. (2015) reports the Global Hawk Whole Air Sampler (GWAS) measurements of $\mathrm{CH}_{3} \mathrm{Br}$ (contribution 1), the halons (contribution 2), and the brominated VSLS (contribution 3) analyzed in whole-air samples, which were simultaneously taken from aboard the NASA Global Hawk over the eastern and western Pacific during the 2013 and 2014 deployments, respectively.

The paper is organized as follows. Section 2 briefly describes all key methods used in the present study. Section 3 discusses the measurements along with some (necessary) data reduction. In Sect. 4, the major observations are presented and they are compared with previous $\mathrm{BrO}$ measurements and our modeling results, along with their implications for the amount of inorganic bromine present within the TTL. Further implications of our measurements for the photochemistry of bromine and ozone within the TTL and lowermost subtropical stratosphere are discussed. Section 5 concludes the study.

\section{Methods}

The instruments of the NASA-ATTREX package most important for the present study consist of a fast UV photometer for measurement of ozone (Gao et al., 2012), a gas chromatograph (Unmanned Aircraft System Chromatograph for Atmospheric Trace Species - UCATS; Wofsy et al., 2011, and Moore et al., 2003) as well as a Picarro instrument (Harvard University Picarro Cavity Ringdown Spectrometer HUPCRS; Crosson, 2008; Rella et al., 2013; Chen et al., 2013) to measure $\mathrm{CH}_{4}, \mathrm{CO}_{2}$, and $\mathrm{CO}$, a whole-air sampler (GWAS; Schauffler et al., 1998, 1999) to analyze a large suite of stable trace gases, and a three-channel scanning limb miniDOAS (differential optical absorption spectroscopy) instrument for spectroscopic detection of $\mathrm{O}_{3}, \mathrm{NO}_{2}, \mathrm{BrO}, \mathrm{OClO}$, $\mathrm{IO}, \mathrm{O}_{4}, \mathrm{O}_{2}, \mathrm{H}_{2} \mathrm{O}_{\text {vapor }}, \mathrm{H}_{2} \mathrm{O}_{\text {liquid, }}$, and $\mathrm{H}_{2} \mathrm{O}_{\text {solid }}$ in the UV-visnear-IR spectral ranges (e.g., Weidner et al., 2005; Platt and 
Stutz, 2008; Kritten et al., 2010, 2014; Kreycy et al., 2013; Stutz et al., 2016).

All instruments, techniques, methods, and tools are briefly described in the following.

\subsection{DOAS measurements of $\mathrm{O}_{3}, \mathrm{NO}_{2}$, and $\mathrm{BrO}$}

The mini-DOAS instrument is a UV-vis-near-IR threechannel optical spectrometer by which scattered skylight received from limb direction and direct sunlight can be analyzed for $\mathrm{O}_{3}, \mathrm{NO}_{2}$, and $\mathrm{BrO}$ (as well as for some other species; see above). Since the instrument and retrieval methods are described in detail in the accompanying paper by Stutz et al. (2016) (for further details, see Table 2 therein), only some key elements of the data analysis are described here.

The post-flight analysis of the collected data for the detection of $\mathrm{O}_{3}, \mathrm{O}_{4}, \mathrm{NO}_{2}$, and $\mathrm{BrO}$ and concentration retrieval include (a) the spectral retrieval of the targeted gases using the DOAS method (Platt and Stutz, 2008) (for the DOAS settings, see Table 4 in Stutz et al., 2016), (b) forward radiative transfer (RT) modeling of each observation using the Monte Carlo model McArtim (Monte Carlo Atmospheric Radiative Transfer Inversion Model; Deutschmann et al., 2011; for further details, see Sect. 2.6), and (c) for the concentration and profile retrieval either the nonlinear optimal estimation (Rodgers, 2000) or the novel $x$ gas scaling technique (for details, see Sect. 4.2. and 4.3 in Stutz et al., 2016). Typical errors are $\pm 5 \mathrm{ppb}$ for $\mathrm{O}_{3}, \pm 15 \mathrm{ppt}$ for $\mathrm{NO}_{2}$, and $\pm 0.5 \mathrm{ppt}$ for $\mathrm{BrO}$, to which possible systematic errors in the individual absorption cross section need to be added. These are for $\mathrm{O}_{3}$-UV $\pm 1.3 \%, \mathrm{O}_{3}$-vis $\pm 2 \%, \mathrm{NO}_{2} \pm 2 \%$, and $\mathrm{BrO} \pm 10 \%$ (for more details on the error budget, see Stutz et al., 2016).

\subsection{In situ measurements of $\mathrm{O}_{3}$}

The NOAA-2 polarized $\mathrm{O}_{3}$ photometer (Gao et al., 2012) is a derivative of the dual-beam, unpolarized, UV absorption technique described by Proffitt and McLaughlin (1983). Briefly, the ambient and $\mathrm{O}_{3}$-free air flow is alternately directed into two identical $60 \mathrm{~cm}$ long absorption cells. The $253.7 \mathrm{~nm}$ UV light from a mercury lamp is split into two beams that are each directed into one of the absorption cells. Since $\mathrm{O}_{3}$ strongly absorbs $253.7 \mathrm{~nm}$ photons, the UV beam passing through the cell containing ambient ozone is attenuated more than the beam passing through the cell containing $\mathrm{O}_{3}$-free air. Knowing the $\mathrm{O}_{3}$ absorption cross section $\left(\sigma\left(\mathrm{O}_{3}\right)\right)$ and the absorption path length $(L)$, the $\mathrm{O}_{3}$ partial pressure $\left(p\left(\mathrm{O}_{3}\right)\right)$ in the ambient air can be derived using Beer's law.

The instrument has a fast sampling rate $(2 \mathrm{~Hz}$ at $<200 \mathrm{hPa}$, $1 \mathrm{~Hz}$ at 200 to $500 \mathrm{hPa}$, and $0.5 \mathrm{~Hz}$ at $\geq 500 \mathrm{hPa}$ ), high accuracy ( $3 \%$ excluding operation in the $300-450 \mathrm{hPa}$ range, where the accuracy may be degraded to about $5 \%$ ), and excellent precision $\left(1.1 \times 10^{10} \mathrm{O}_{3}\right.$ molecules $\mathrm{cm}^{-3}$ at $2 \mathrm{~Hz}$, which corresponds to $3.0 \mathrm{ppb}$ at $200 \mathrm{~K}$ and $100 \mathrm{hPa}$ or $0.41 \mathrm{ppb}$ at $273 \mathrm{~K}$ and $1013 \mathrm{hPa}$ ). The size (36 L), weight $(18 \mathrm{~kg})$, and power $(50-200 \mathrm{~W})$ make the instrument suitable for many unmanned aerial vehicle systems and other airborne platforms. In-flight and laboratory intercomparisons with existing $\mathrm{O}_{3}$ instruments have shown that measurement accuracy $(3 \%)$ is maintained in flight.

\section{$2.3 \mathrm{CH}_{4}$ measurements by UCATS}

The UCATS measures atmospheric methane $\left(\mathrm{CH}_{4}\right)$ on one gas chromatographic channel along with hydrogen $\left(\mathrm{H}_{2}\right)$ and carbon monoxide (CO) once every $140 \mathrm{~s}$. UCATS has two chromatographic channels with electron capture detectors (ECDs), two ozone $\left(\mathrm{O}_{3}\right)$ ultraviolet absorption spectrometers, and a water vapor $\left(\mathrm{H}_{2} \mathrm{O}\right)$ tunable diode laser absorption spectrometer (TDLAS). The details of the $\mathrm{CH}_{4}$ chromatography are similar to those on balloon and airborne instruments described in Moore et al. (2003) and Elkins et al. (1996). The addition of $\sim 100 \mathrm{ppm}$ of nitrous oxide to the make-up line of the ECD enhances the sensitivity to $\mathrm{H}_{2}, \mathrm{CO}$, and $\mathrm{CH}_{4}$ (Elkins et al., 1996, and Moore et al., 2003). The separation of these gases in air is accomplished with a pre-column of Unibeads ( $2 \mathrm{~m} \times 2 \mathrm{~mm}$ diameter), and a main column of molecular sieve $5 \mathrm{~A}(0.7 \mathrm{~m} \times 2.2 \mathrm{~mm}$ diameter $)$ at $\sim 110^{\circ} \mathrm{C}$ (Moore et al., 2003). The precision of the $\mathrm{CH}_{4}$ measurement during ATTREX was $\pm 0.5 \%$ and is calibrated during flight with a secondary standard after every three ambient air measurements. Instrumental drift is corrected between the standard injections. UCATS measurements are traceable to the WMO Central Calibration Laboratory (CCL) and are on the $\mathrm{CH}_{4}$ WMO X2004A scale (Dlugokencky et al., 2005, with updates given at http://www.esrl.noaa.gov/gmd/ $\mathrm{ccl} / \mathrm{ch} 4$ _scale.html).

\section{$2.4 \mathrm{CH}_{4}$ measurements by HUPCRS}

The HUPCRS consists of a G2401-m Picarro gas analyzer (Picarro Inc., Santa Clara, CA, USA) repackaged in a temperature-controlled pressure vessel, a separate calibration system with two multi-species gas standards, and an external pump and pressure control assembly designed to allow operation at a wide range of altitudes. The Picarro analyzer uses wavelength-scanned cavity ringdown spectroscopy (WS-CRDS) technology to make high-precision measurements of greenhouse gases (Crosson, 2008; Rella et al., 2013; Chen et al., 2013). HUPCRS reports concentrations of $\mathrm{CO}_{2}, \mathrm{CH}_{4}$, and $\mathrm{CO}$ every $\sim 2.2 \mathrm{~s}$ and the data are averaged to $10 \mathrm{~s}$. In-flight precision for $\mathrm{CH}_{4}$ is $0.2 \mathrm{ppb}$ in $10 \mathrm{~s}$.

Briefly, the analyzer uses three distributed feedback (DFB) diode lasers in the spectral region of 1.55 to $1.65 \mu \mathrm{m}$. Monochromatic light is injected into a high-finesse optical cavity with a volume of $35 \mathrm{~cm}^{3}$ and a configuration of three highly reflective mirrors ( $\geq 99.995 \%)$. Internal control loops 


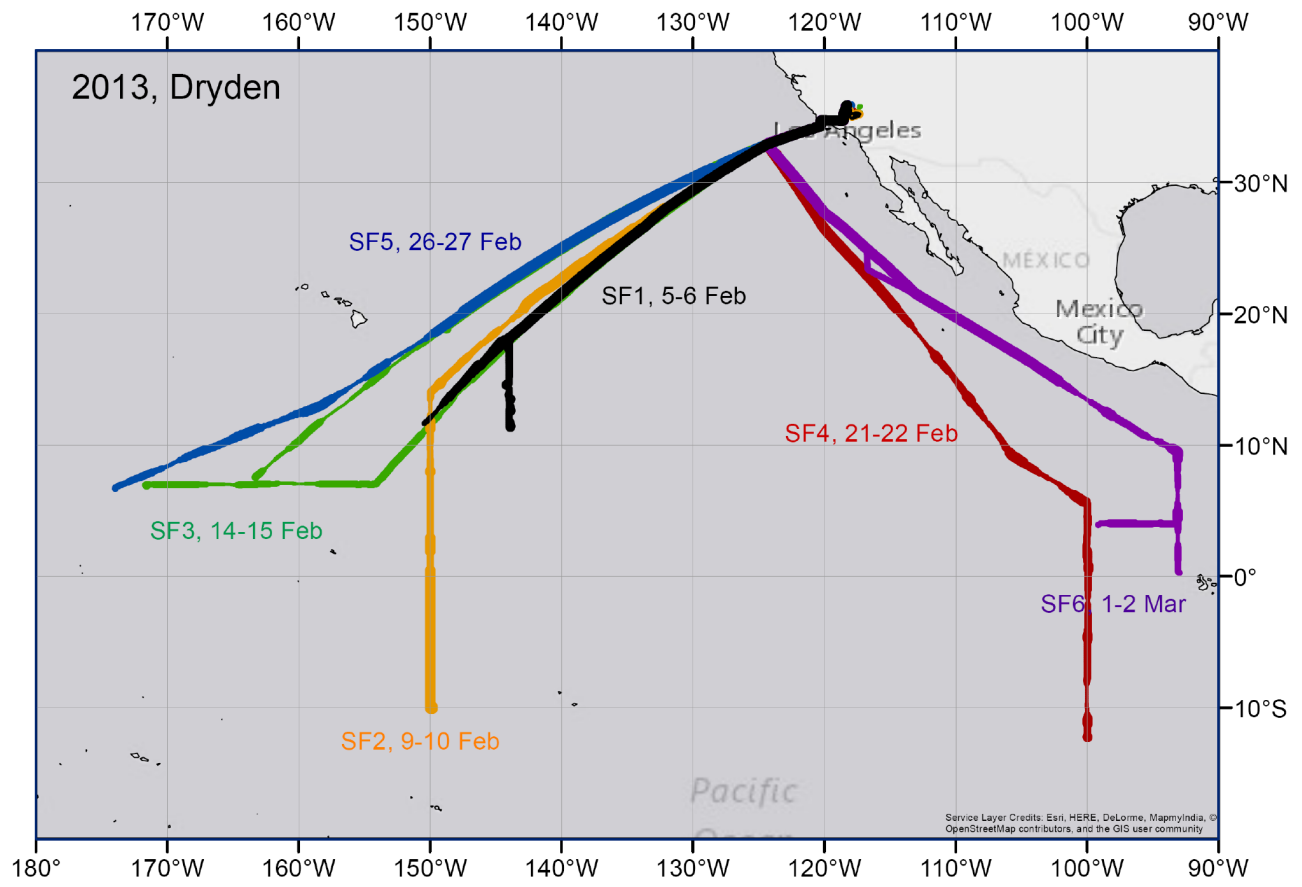

Figure 1. Overview of the NASA Global Hawk ATTREX flights conducted from Dryden in 2013. The thickness of the lines corresponds to flight altitudes, where the thinnest line is for an altitude of around $14 \mathrm{~km}$ and the thickest line for around $18 \mathrm{~km}$.

keep the cavity at $140 \pm 0.02$ Torr and $45 \pm 0.0005^{\circ} \mathrm{C}$ in order to stabilize the spectra. The injected light is blocked periodically, and when blocked, the exponential decay rate of the light intensity is measured by a photodetector. The decay rate depends on loss mechanisms within the cavity such as mirror losses, light scattering, refraction, and absorption by a specific analyte. A sequence of specific wavelengths for each molecule is injected into the cavity in order to reconstruct the absorption spectra. A fit to the spectra is performed in real time and concentrations are derived based on peak height. High-altitude sampling (i.e., very low pressure and temperature) necessitated transferring the core components of the Picarro analyzer to a sealed tubular pressure vessel, which is maintained at $35^{\circ} \mathrm{C}$ and 760 Torr. The analyzer's components are isolated from the pressure vessel to provide vibration damping and decoupling from deformations in the pressure vessel caused by external pressure changes.

The sampling strategy for HUPCRS consists of bringing in air through a rear-facing inlet, filtered by a $2 \mu \mathrm{m}$ Zefluor membrane, and dehydrating this air by flowing it through a multi-tube Nafion dryer followed by a dry-ice cooled trap prior to entering the Picarro analyzer. A choked upstream Teflon-lined diaphragm pump delivers ambient air to the analyzer at 400 Torr, regardless of aircraft altitude, via a flow bypass. A similar downstream pump, with an inlet pressure of 10 Torr, facilitates flow through the analyzer at high altitude and ensures adequate purging of the Nafion drier. Measurement accuracy and stability are monitored by replacing ambient air with air from two NOAA-traceable gas standards (low- and high-span) for a total of $4 \mathrm{~min}$ every $30 \mathrm{~min}$. These standards are contained in $8.4 \mathrm{~L}$ carbon fiber wrapped aluminum cylinders and housed in a temperature-controlled enclosure. The total weight of the package is $97 \mathrm{~kg}$.

\subsection{The Global Hawk Whole Air Sampler}

The GWAS is a modified version of the Whole Air Sampler used on previous airborne campaigns (Heidt et al., 1989; Schauffler et al., 1998, 1999; Daniel et al., 1996). Briefly, the instrument consists of 90 custom-made Silonite-coated (Entech Instruments, Simi Valley, CA) canisters of $1.3 \mathrm{~L}$, controlled with Parker Series 99 solenoid valves (ParkerHannifin, Corp., Hollis, NH). Two metal bellows compressor pumps (Senior Aerospace, Sharon, MA) allow the flow of ambient air through a custom inlet at flow rates ranging from 2 to 8 standard $\mathrm{L} \mathrm{min}^{-1}$, depending on altitude. The manifold and canister module temperatures are controlled to remain within the range of $0-30^{\circ} \mathrm{C}$. GWAS is a fully automated instrument controlled from the ground through an Ethernet interface. Parameters to fill the canisters, flush the manifold, and control the temperature are predetermined in the data system module (DSM) inside the aircraft, to fill the canisters automatically in the case of failure of the aircraft networks. However, during the entire flight, the parameters are manually set with the ground laptop computer to improve the sampling collection at different altitudes. During the ATTREX campaign, the canisters were filled to $\sim 3$ standard atmospheres (40 psi) in about $25 \mathrm{~s}$ at $14 \mathrm{~km}$ and $90 \mathrm{~s}$ at 
$18 \mathrm{~km}$. The samples are analyzed using a high-performance gas chromatograph (Agilent Technology 7890A) and mass spectrometer with mass selective, flame ionization and electron capture detectors (Agilent Technology 5975C). Samples are concentrated on an adsorbent tube at $-38^{\circ} \mathrm{C}$ with a combination of cryogen-free automation and thermal desorber system (CIA Advantage plus UNITY 2, Markes International). The oven temperature profile is $-20^{\circ} \mathrm{C}$ for $3 \mathrm{~min}$, then $10^{\circ} \mathrm{C} \mathrm{min}^{-1}$ to $200^{\circ} \mathrm{C}$, and $200^{\circ} \mathrm{C}$ for 4 min for a total analysis time of $29 \mathrm{~min}$. Under these sampling conditions the precision is compound/concentration dependent and ranged from $\leq 2$ to $20 \%$. Calibration procedures as well as mixing ratio calculations are described elsewhere (Schauffler et al., 1999).

During ATTREX 2013 the whole-air sampler measured a variety of organic trace gases, including non-methane hydrocarbons, CFCs, HCFCs, methyl halides, solvents, organic nitrates, and selected sulfur species. For this work a range of long- and short-lived organic bromine gases are measured, including $\mathrm{CH}_{3} \mathrm{Br}, \mathrm{CH}_{2} \mathrm{Br}_{2}, \mathrm{CH}_{2} \mathrm{BrCl}$, $\mathrm{CHBrCl}_{2}$, $\mathrm{CHBr}_{2} \mathrm{Cl}, \mathrm{CHBr}_{3}$, and halon-1211 $\left(\mathrm{CBrClF}_{2}\right)$ and halon $2402\left(\mathrm{C}_{2} \mathrm{Br}_{2} \mathrm{~F}_{4}\right)$. Halon-1301 $\left(\mathrm{CBrF}_{3}\right)$ is not measured and a constant value of $3.3 \mathrm{ppt}$ is used to account for the bromine content from this compound.

\subsection{Radiative transfer modeling}

The measured limb radiances of the mini-DOAS instrument are modeled in spherical 1-D and in selected cases in 3-D, using version 3.5 of the Monte Carlo RT model McArtim (Deutschmann et al., 2011). The model's input is chosen according to the on-board measured atmospheric temperatures and pressures, including climatological low-latitude aerosol profiles from Stratospheric Aerosol and Gas Experiment III (SAGE III) (https://eosweb.larc.nasa.gov/project/sage3/ sage3_table), and lower-atmospheric cloud covers as indicated by the cloud physics lidar measurements made from aboard the Global Hawk (GH; see http://cpl.gsfc.nasa.gov/). In the standard run, the ground (oceanic) albedo is set to 0.07 in UV and 0.2 in the visible spectral range. The RT model is further fed with the actual geolocation of the GH, solar zenith, and azimuth angles as encountered during each measurement, the telescopes azimuth and elevation angles, as well as the field of view (FOV) of the mini-DOAS telescopes. Figure 5 in Stutz et al. (2016) displays one example of an RT simulation for limb measurements at $18 \mathrm{~km}$ altitude. The simulation indicates that correctly accounting for the Earth's sphericity, the atmospheric refraction, cloud cover, ground albedo, etc., is relevant for the interpretation of UV-vis-nearIR limb measurements performed within the middle atmosphere (Deutschmann et al., 2011). Even though the three (UV-vis-near-IR) mini-DOAS spectrometers are not radiometrically calibrated on a absolute scale, past comparison exercises of measured and McArtim modeled limb radiance provide confidence in the quality of the RT simulations (see, e.g., Figs. 5 and 6 in Deutschmann et al., 2011, and Fig. 2 in Kreycy et al., 2013).

For the simulations of the trace gas absorptions measured in limb direction, the RT model is further fed with TOMCAT/SLIMCAT-simulated curtains of the targeted gases simulated along the GH flight paths (see Sect. 2.7). In the RT simulations $[\mathrm{BrO}]$ is set to $0.5 \mathrm{ppt}$ near the ground, where TOMCAT/SLIMCAT predicts lower BrO concentrations (see Fig. 2 middle right panel), in agreement with the findings discussed in Stutz et al. (2016) and the recent study of Schmidt et al. (2016).

\subsection{Photochemical modeling}

For the interpretation of our measurements, we use simulations of the TOMCAT/SLIMCAT 3-D chemical transport model (CTM; Chipperfield, 1999, 2006). More specifically, the simulations are used for intercomparison with measured photochemical species, for assessment of the budget of $\operatorname{Br}_{y}^{\text {inorg }}$, and for sensitivity studies on the impact of our measurements on the photochemistry of bromine and ozone in the subtropical UT-LS, tropical UT, and TTL.

For the present study, the TOMCAT/SLIMCAT model is driven by meteorology from the ECMWF ERAinterim reanalyses (Dee et al., 2011). The reanalyses are used for large-scale winds and temperatures as well as convective mass fluxes (Feng et al., 2011). The model has a detailed stratospheric chemistry scheme with kinetic and photochemical data taken from JPL2011 (Sander et al., 2011), with recent updates. The model chemical fields are constrained by specified timedependent surface mixing ratios. For the brominated species, the following surface mixing ratios of stratosphericrelevant source gases are assumed: $\left[\mathrm{CH}_{3} \mathrm{Br}\right]=6.9 \mathrm{ppt}$; [halons $]=7.99 \mathrm{ppt} ;\left[\mathrm{CHBr}_{3}\right]=1 \mathrm{ppt} ;\left[\mathrm{CH}_{2} \mathrm{Br}_{2}\right]=1 \mathrm{ppt}$; and $\Sigma\left[\mathrm{CHClBr}_{2}, \mathrm{CHCl}_{2} \mathrm{Br}, \mathrm{CH}_{2} \mathrm{ClBr}\right.$, etc. $]=1 \mathrm{ppt}$ of $\mathrm{Br}$. Organic bromine is thus $\left[\mathrm{Br}_{y}^{\mathrm{org}}\right]=20.89 \mathrm{ppt}$ at the surface, in agreement with recent reports (e.g., WMO, 2014; Sala et al., 2014). No other (unknown organic or inorganic) sources of bromine for UT, LS, and TTL are assumed (e.g., Fitzenberger et al., 2000; Salawitch et al., 2010; Wang et al., 2015). Omitting the release and heterogeneous processing of bromine from sea-salt aerosols (e.g., Saiz-Lopez et al., 2004) in the model for the sake of saving computing time appears justified since (1) even though it is predicted to be relevant for bromine $\left(\sim 30 \%\right.$ of the total $\left.\mathrm{Br}_{y}^{\text {inorg }}\right)$ in the free troposphere (Schmidt et al., 2016), its contribution to $\mathrm{BrO}$ in the TTL is at most of the order of the accuracy $(\sim 0.5 \mathrm{ppt})$ of our BrO measurements, (2) its time- and space-dependent sources (as for the brominated VSLS) are not well constrained, (3) in the modeled troposphere inorganic bromine only serves as a boundary condition for bromine in the TTL, and (4) the additional $\mathrm{BrO}$ would not affect the BrO-measurement-based calculation of $\mathrm{Br}_{y}^{\text {inorg }}$ for the TTL (see below). Further, the surface concentration of $\mathrm{CH}_{4}$ is specified based on observa- 

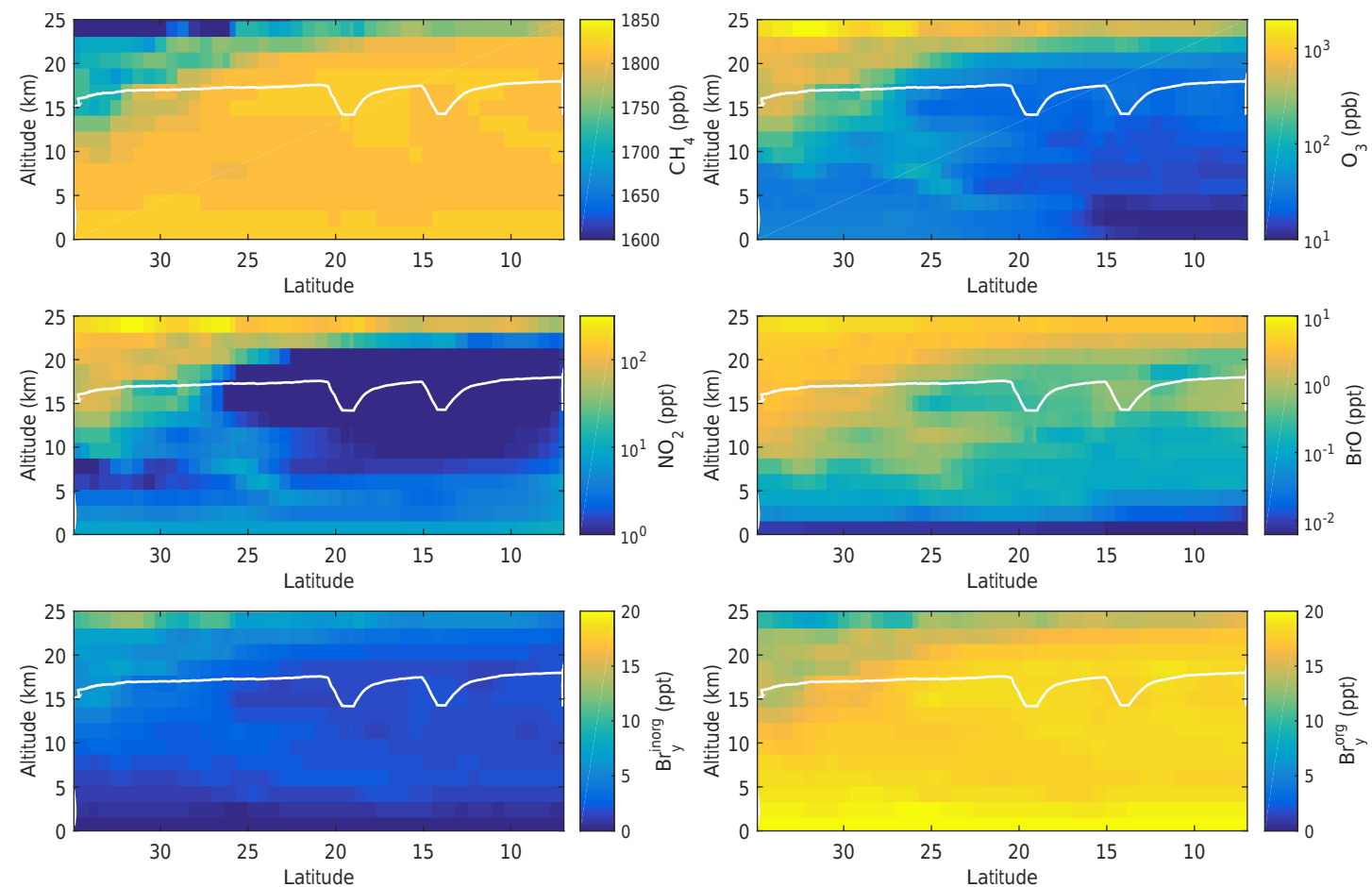

Figure 2. TOMCAT/SLIMCAT predictions of mixing ratio curtains of $\mathrm{CH}_{4}$ (upper left), $\mathrm{O}_{3}$ (upper right), $\mathrm{NO}_{2}$ (middle left), $\mathrm{BrO}$ (middle right), $\mathrm{Br}_{y}^{\text {inorg }}$ (bottom left), and $\mathrm{Br}_{y}^{\text {org }}$ (bottom right) for the sunlit part of SF3-2013 (14 February 2013). Note the different color scale ranges. The white line is the flight trajectory of the Global Hawk. For better visibility, the simulated mixing ratios are shown for the altitude range $0-25 \mathrm{~km}$, although the TOMCAT/SLIMCAT simulations cover the range of $0-63 \mathrm{~km}$ altitude.

tions of AGAGE (Advanced Global Atmospheric Gases Experiment; https://agage.mit.edu/) and NOAA, which reflect recent variations in its growth rate.

The standard model run (no. 583) is initialized in 1979 and spun-up for 34 years at low horizontal resolution $\left(5.6^{\circ} \times 5.6^{\circ}\right)$ and with 36 unevenly spaced sigma-pressure vertical levels in the altitude range $0-63 \mathrm{~km}$. Output from 1 January 2013 is interpolated to a high horizontal resolution $\left(1.2^{\circ} \times 1.2^{\circ}\right)$, and the simulation continued over the ATTREX campaign period using this resolution. The model output is sampled online along the Global Hawk flight tracks for direct comparison with the observations. Two further highresolution sensitivity experiments are performed from 1 January 2013 onwards. In run no. 584, the ratio of the photolysis frequency of $\mathrm{BrONO}_{2}$ and the three-body association rate reaction coefficient $\mathrm{k}_{\mathrm{BrO}+\mathrm{NO}_{2}}$ is increased by a factor 1.75 (e.g., Kreycy et al., 2013). In run no. 585 the second-order rate reaction coefficient $\mathrm{k}_{\mathrm{Br}+\mathrm{O}_{3}}$ is set to the upper limit of its uncertainty range (Sander et al., 2011).

For all model levels and for the time resolution $(\sim 30 \mathrm{~s})$ of the mini-DOAS measurements, "curtains" of the targeted gases along the flight track are stored (see, e.g., Fig. 6 in Stutz et al., 2016, and Fig. 2 of our present study). They are imported into the RT model McArtim for further forward simulations of the observations, and measurement-versus-model intercomparison studies. The inclusion of simulated TOM-
CAT/SLIMCAT curtains in our study is particularly necessary for (a) the retrieval of absolute concentrations using the $\mathrm{O}_{3}$-scaling technique (see Stutz et al., 2016, Sect. 4.3), (b) estimate of errors and retrieval sensitivities to various parameters (see Sect. 4.4 and the Supplement to Stutz et al., 2016), (c) the separation of dynamical and photochemical processes in the interpretation of our data, (d) sensitivity tests for the assumed kinetic data, and (e) the assessment of total $\mathrm{Br}_{y}^{\text {inorg }}$ (see Sect. 4).

Finally, details of how the loss in ozone is calculated is provided in Appendix Sect. A.

\section{Measurements and data reduction}

Within the framework of the NASA-ATTREX project, the Global Hawk performed six flights in the subtropical LS, UT, and TTL over the eastern Pacific in early 2013 (Fig. 1) and another nine flights over the western Pacific in early 2014. The present paper reports the 2013 flights since the 2014 flights were mostly performed in the cold TTL, where cirrus clouds mostly prevailed at flight level. Evidently, due to the multiple scattering of light by the cirrus cloud particles, the interpretation of our UV-vis limb measurements is not straightforward. Accordingly, the data collected in 2014 will be reported elsewhere. Details on the NASA-ATTREX 2013 

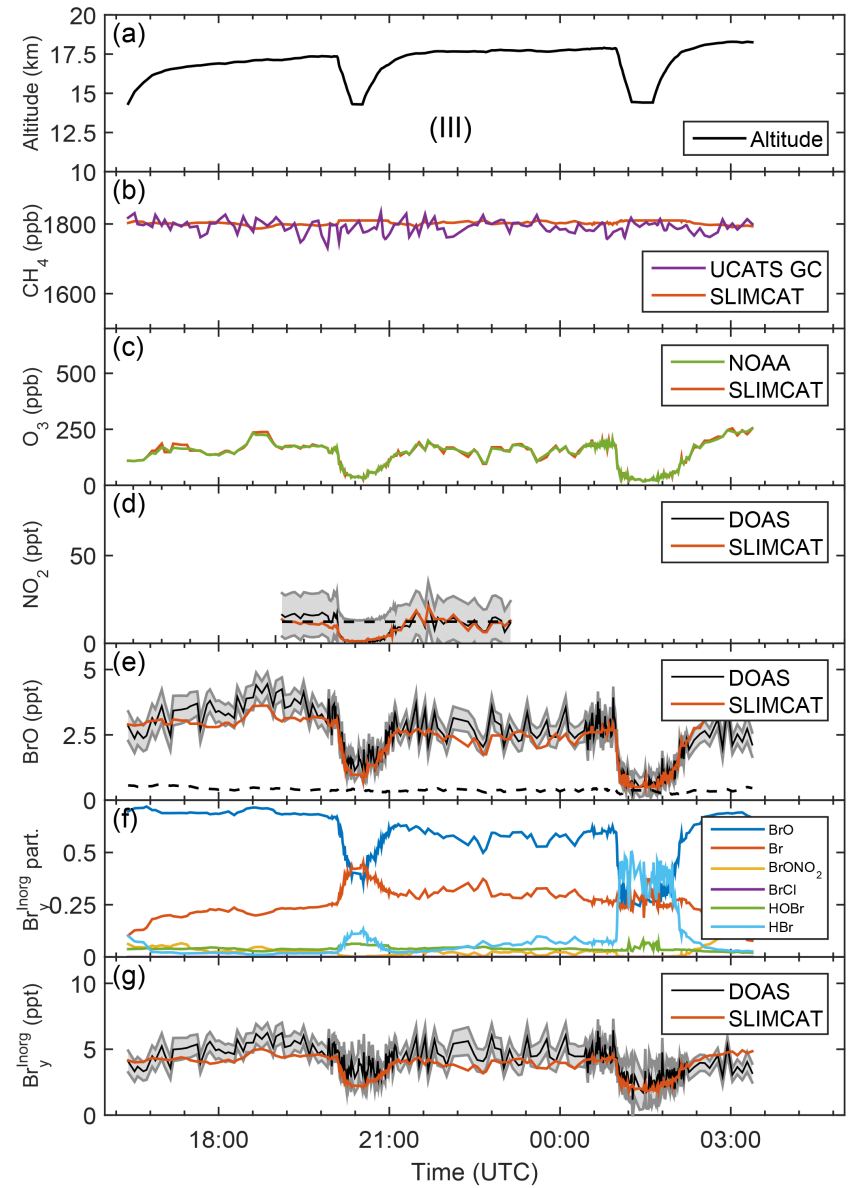

Figure 3. Panel (a) shows the time-altitude trajectory of the sunlit part of the GH flight track (SF1-2013) on 4-5 February 2013 (SF1-2013). Panels (b)-(e) show intercomparisons of TOMCAT/SLIMCAT-simulated fields with observations of (b) $\mathrm{CH}_{4}$ (UCATS), (c) $\mathrm{O}_{3}$ (NOAA), (d) $\mathrm{NO}_{2}$ (mini-DOAS), and (e) $\mathrm{BrO}$ (mini-DOAS). The grey-shaded error bars of the mini-DOAS $\mathrm{NO}_{2}$ and $\mathrm{BrO}$ measurements include all significant errors, i.e., the spectral retrieval error, the error due to a contribution to the slant absorption from above the aircraft and from the troposphere, and the absorption cross section uncertainty. Panel (f) shows the SLIMCAT modeled $\mathrm{Br}_{y}$ partitioning for the standard run no. 583. Panel (g) shows a comparison of inferred and modeled $\mathrm{Br}_{y}^{\text {inorg }}$, including the uncertainty as a grey band.

instrument package, the flights, and some results of the collected data can be found in Jensen et al. $(2013,2015)$, as well as on the project's website https://espo.nasa.gov/missions/ attrex/content/ATTREX.

In February and March 2013, the NASA-ATTREX flights of the Global Hawk were strongly biased with respect to the sampled air masses, mostly because the scientific interest was primarily put on probing the TTL over the eastern Pacific for aerosols and cirrus cloud particles during the convective season rather than for the photochemistry of bromine in the LS, UT, and TTL (see Fig. 1). Therefore, and due to opera-

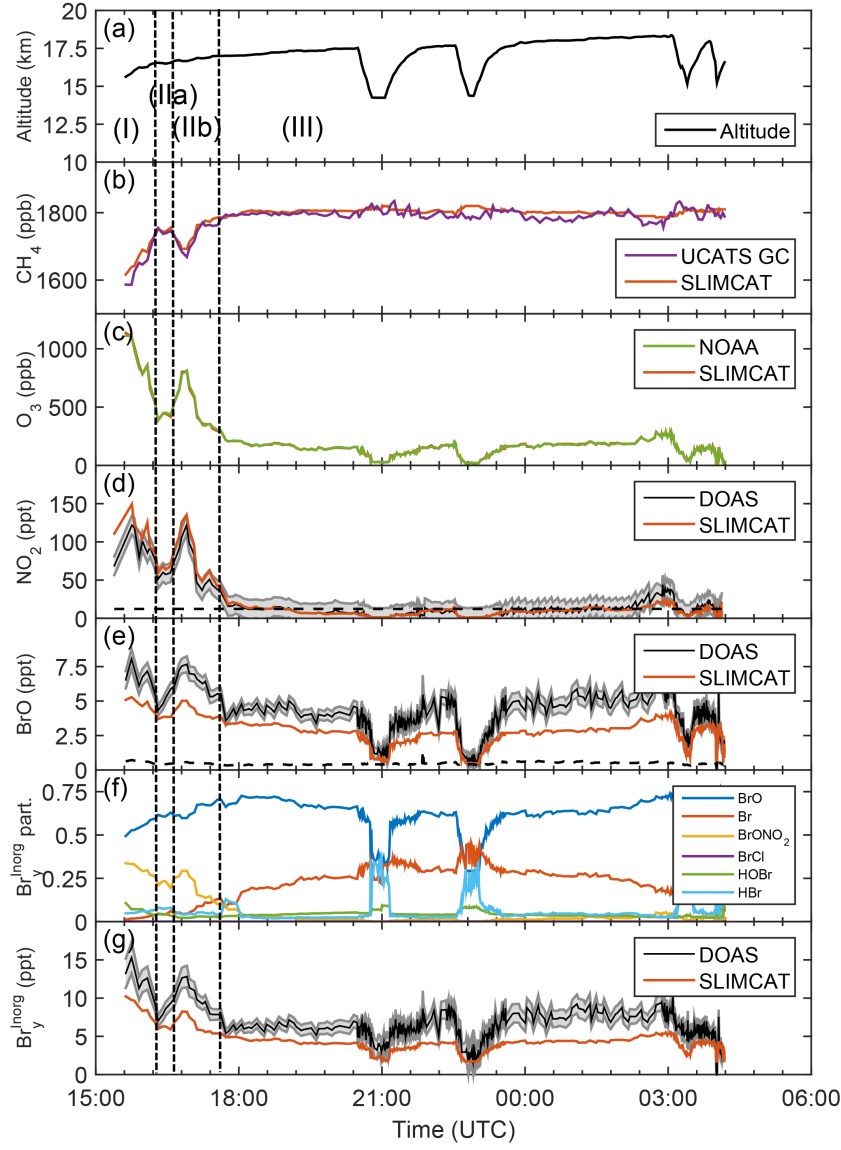

Figure 4. Same as Fig. 3 but for the research flight on 9-10 February 2013 (SF2-2013). The dashed vertical lines in Figs. 4-9 separate different atmospheric regimes: (I) is the extratropical lowermost stratosphere; (IIa, IIb, etc.) are different mixing regimes of air from the extratropical lowermost stratosphere; and (III) is from the tropical tropopause layer.

tional reasons, typical flight patterns extended from Dryden, California, in a southerly or southwesterly direction during daytime until a turn-point was reached, and the back leg to Dryden in a northeasterly direction occurred during the night when the mini-DOAS instrument could not take measurements. The dives were mostly performed within the TTL and occasionally within the subtropical lowermost stratosphere during the return legs at night but not during the outgoing daytime legs. Finally the landings at Dryden were scheduled for the early local morning, mostly due to operational constraints. Therefore, no profiles of the targeted species could be obtained in the subtropical lowermost stratosphere during the daytime, but a large number were obtained within the UT and TTL.

Furthermore, the latitudinal definition of the notations "subtropical" LS and "tropical" TTL need some clarification. According to the definition of Fueglistaler et al. (2009), the latitudinal boundary between the subtropics and tropics 
should be where the subtropical jet is located. However, since we do not infer dynamical parameters (such as the potential vorticity) from our data, we conveniently define the boundary according to proxies for (a) different air mass ages (i.e., $\left[\mathrm{CH}_{4}\right]$ concentrations $\leq 1790 \mathrm{ppb}$ are labeled subtropical and $\left[\mathrm{CH}_{4}\right] \geq 1790 \mathrm{ppb}$ are labeled tropical) and (b) photochemical regimes (i.e., $\left[\mathrm{O}_{3}\right]$ is subtropical when $\left[\mathrm{O}_{3}\right] \geq 150 \mathrm{ppb}$ and TTL when $\left[\mathrm{O}_{3}\right] \leq 150 \mathrm{ppb}$ ), which we find suitable from a visual inspection of our data (see below).

As mentioned above and outlined in detail in the study of Stutz et al. (2016), the processing of the mini-DOAS data included (a) spectral retrieval of the targeted gases from the mini-DOAS measurements (Sect. 2.1), (b) forward modeling of the RT for each measured spectrum (Sect. 2.6), and (c) either applying optimal estimation or the novel $x$ gas scaling technique (see Sect. 4.1 and 4.2 in Stutz et al., 2016). Comprehensive sensitivity simulations indicated that optical estimation based on constraints inferred from measured $\mathrm{O}_{4}$ and/or relative radiance would not result in the desired error range (Stutz et al., 2016, Sect. 4.2). Therefore, we decided to apply the $x$ gas scaling technique (Stutz et al., 2016, and Raecke, 2013) with $x$ being ozone measured in situ by the NOAA-2 $\mathrm{O}_{3}$ photometer (see Sect. 2.2).

The $\mathrm{O}_{3}$-scaling technique makes use of the in situ $\mathrm{O}_{3}$ measured by the NOAA instrument (Gao et al., 2012) and the limb-measured $\mathrm{O}_{3}$ total slant column amounts $\left(\mathrm{SCD}_{\mathrm{O} 3}\right)$ either monitored in the UV (for the retrieval of $\mathrm{BrO}$ in the 343-355 nm wavelength band) or visible wavelength range (for the retrieval of $\mathrm{NO}_{2}$ in the 424-460 $\mathrm{nm}$ wavelength band; see Eq. 12 in Stutz et al., 2016). Here the ratio of the measured slant column and $\mathrm{SCD}_{\mathrm{O} 3} /\left[\mathrm{O}_{3}\right]$ measured in situ can be regarded as a proxy for the (horizontal) light path length over which the absorption is collected. In fact, in the paper of Stutz et al. (2016), it is argued that the so-called $\alpha$ factors account for the fraction of the absorption of the scaling gas $x$ (e.g., $x=\mathrm{O}_{3}$ in our study) picked up on the horizontal light paths ahead of the aircraft relative to the total measured absorption. The sensitivity study on the $\alpha$ factors presented in Stutz et al. (2016) (e.g., in the Supplement) indicates that for the targeted gases, uncertainties in $\alpha$ factor ratios due to assumptions regarding the RT (for example due to Mie scattering by aerosols and clouds) mostly cancel out, while uncertainties in the individual profile shapes of the targeted and scaling gas are most relevant for the errors of the inferred gas concentrations. Therefore, in the present study, profile shapes of the targeted and scaling gas predicted by the TOMCAT/SLIMCAT CTM are used in the RT calculations, aiming at the calculation of the $\alpha$ factors. The uncertainties in the profile shapes (assumed to be of the order of the altitude adjustment of the $\mathrm{CH}_{4}$ and $\mathrm{O}_{3}$ curtains, which are typically much smaller than the altitude grid spacing in the SLIMCAT/TOMCAT simulations) are then carried over to calculate the overall errors, as discussed in Sect. 4.4 of the Stutz et al. (2016) study.
It should be noted that for the flight on 21 February 2013 (SF4-2013), the DOAS retrieval is much less robust than for all the other flights, most likely because the Fraunhofer reference spectra (taken via a diffuser) are affected by temporally changing residual structures likely due to ice deposits or some other residues on the entrance diffuser. Therefore, the data of this flight are not analyzed in detail, but they are only reported for completeness here.

Finally, in our analysis only those data which are taken at a solar zenith angle (SZA) $\leq 88^{\circ}$ are considered because for increasing SZAs the received skylight radiance requires increasingly longer signal integration times (longer than the standard integration time, which is $30 \mathrm{~s}$ ) and are thus averaged over longer distances ahead of the aircraft. Moreover, as the SZA increases, the skylight is expected to traverse an increasingly inhomogeneous curtain of the probed radicals (e.g., see Figs. 5 and 6 in Stutz et al., 2016). As a consequence, the spatial grid of TOMCAT/SLIMCAT $\left(1.2 \times 1.2^{\circ}\right)$ on which the photochemistry is simulated appeared too coarse for a useful interpretation of our measurements at large SZAs. Therefore, for a tighter interpretation of our data, a model with higher spatial resolution than provided by TOMCAT/SLIMCAT would be required. Such an approach is for example followed in the balloon-borne studies of Harder et al. (2000), Butz et al. (2009), Kreycy et al. (2013), and others. However, since both processes are likely to increase the error of our analysis and since large SZA $\left(\geq 88^{\circ}\right)$ measurements only constitute a minor part of all measurements, we refrain from this much more complicated approach.

\section{Results and discussion}

In this section we first discuss how our mini-DOAS measurements of $\mathrm{O}_{3}, \mathrm{NO}_{2}$, and $\mathrm{BrO}$, as well as of $\mathrm{CH}_{4}$ (from UCATS and HUPCRS), and of the organic brominated source gases (from GWAS) compare with the model predictions of the TOMCAT/SLIMCAT model (Sects. 4.1 and 4.2). Then measured $\mathrm{BrO}$ is compared with previous measurements in the UT-TTL-LS (Sect. 4.3) and with the model predictions (Sect. 4.4). Uncertainties and errors in the inferred $\mathrm{Br}_{y}^{\text {inorg }}$ are assessed (Sect. 4.5) before implications of our measurements for total $\mathrm{Br}_{y}$ (Sect. 4.6) and impacts of our measurements on TTL ozone are discussed (Sect. 4.7). 


\subsection{Comparison with TOMCAT/SLIMCAT predictions}

Figures 3 to 8 provide overviews on the measured data together with the TOMCAT/SLIMCAT modeled $\mathrm{Br}_{y}^{\text {inorg }}$ partitioning (panels f) and inferred total $\mathrm{Br}_{y}^{\text {inorg }}$ (panels g) as a function of universal time for each flight. The modeled values are obtained by linear interpolation of the curtain data (see Fig. 2) to the exact altitude of the GH.

The panels $b$ and c of Figs. 3 to 8 show comparisons of measured and modeled $\mathrm{CH}_{4}$ and $\mathrm{O}_{3}$ mixing ratios. Here the measured and modeled species closely agree within the given error bars after the modeled curtains are altitude-shifted (i.e., interpolated) by the same amount until measured and modeled $\mathrm{O}_{3}$ agree (for details, see Stutz et al., 2016). It is noteworthy that in most cases the altitude adjustment is less than the grid spacing of TOMCAT/SLIMCAT (about $1 \mathrm{~km}$ in the TTL), thus mostly accounting for the altitude mismatches of the actual cruise altitude of the Global Hawk and the model output rather than indicating deficits of the model in properly predicting the vertical transport. The astonishingly good agreement achieved between measured and modeled $\mathrm{CH}_{4}$, and $\mathrm{O}_{3}$ lends confidence that the altitude-adjusted TOMCAT/SLIMCAT model fields reproduce the essential dynamical and photochemical processes of the probed air masses well. The quality of the dynamical simulations are further tested by comparing modeled and measured $\mathrm{O}_{3}$ as a function of $\mathrm{CH}_{4}$ (Fig. 9). For all flights the agreement of the observed and modeled $\mathrm{O}_{3}$ vs. $\mathrm{CH}_{4}$ correlation is reasonably good, except for flights SF1-2013 and SF2-2013, where the UCATS measured $\mathrm{CH}_{4}$ scatters around the simulated $\mathrm{CH}_{4}$ concentrations. This scatter is most likely due to precision errors of UCATS rather than reflecting the real behavior of the atmosphere. Evidence for this conclusion is provided from the $\mathrm{CH}_{4}$ comparisons for SF3-2013 and SF6-2013, in which the HUPCRS $\mathrm{CH}_{4}$ data are taken; these data do not show such scatter and compare reasonably well with the model predictions.

Panels d of Figs. 3 to 8 compare measured and modeled $\mathrm{NO}_{2}$. Overall, the measured (and modeled) $\mathrm{NO}_{2}$ concentrations meet the expectations with respect to $\mathrm{NO}_{2}$ partitioning and total $\mathrm{NO}_{x}\left(=\mathrm{NO}+\mathrm{NO}_{2}+\mathrm{NO}_{3}\right)$ abundances in the $\mathrm{LS}$, $\mathrm{UT}$, and TTL over the pristine Pacific. Elevated $\mathrm{NO}_{2}$ concentrations (range 70 to $170 \mathrm{ppt}$ ) are measured within the subtropical lowermost stratosphere, where aged air masses are probed, as indicated by depleted $\mathrm{CH}_{4}$ concentrations and elevated $\mathrm{O}_{3}$ concentrations (and presumably decreased $\mathrm{N}_{2} \mathrm{O}$ concentrations). Note that $\mathrm{N}_{2} \mathrm{O}$ is the primary source for stratospheric $\mathrm{NO}_{x}$, and in the stratosphere $\mathrm{CH}_{4}$ and $\mathrm{N}_{2} \mathrm{O}$ destruction processes closely follow each other (e.g., Michelsen et al., 1998; Ravishankara et al., 2009). Very low $\mathrm{NO}_{2}$ concentrations $(\leq 30 \mathrm{ppt})$ are detected within the UT and TTL, indicating that the analyzed air does not originate from recently polluted or lightning-affected regions. Further, the modeled $\mathrm{NO}_{2}$ concentrations (red line in panel d) are found

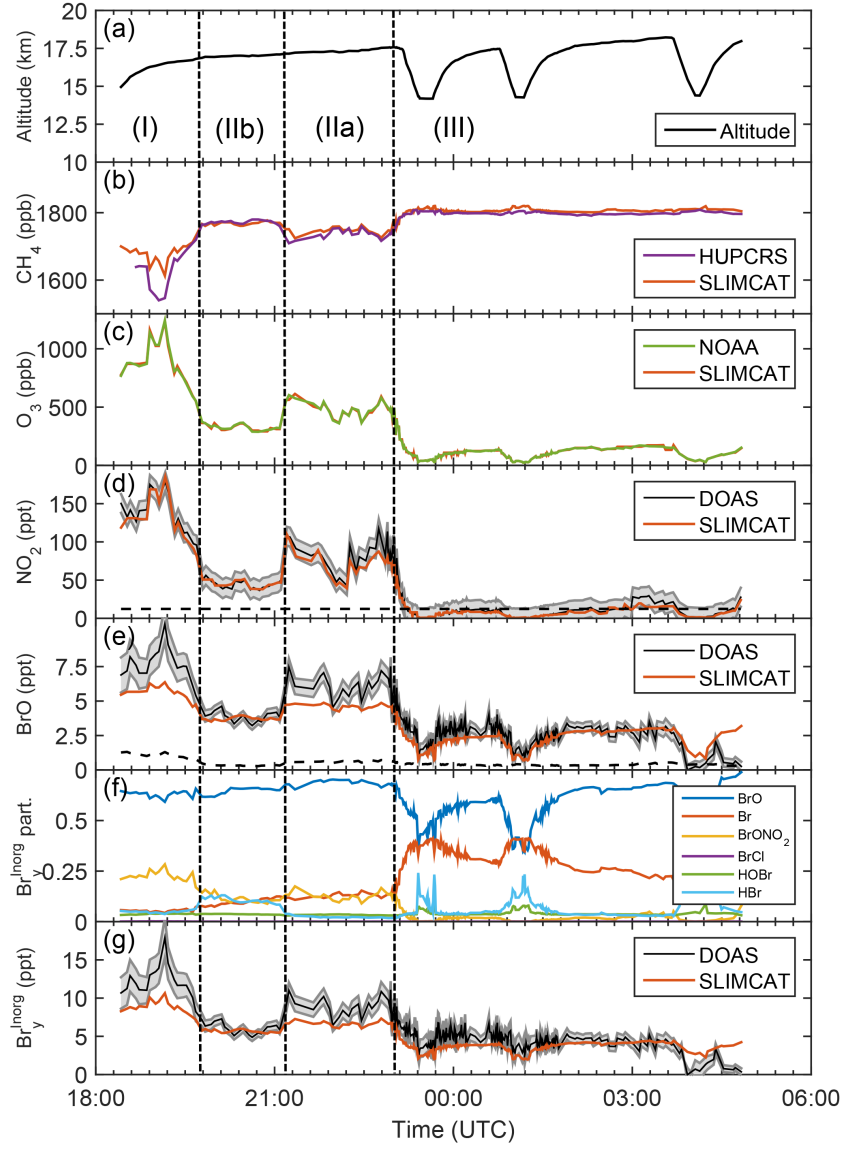

Figure 5. Same as Fig. 3 but for the research flight on 14-15 February 2013 (SF3-2013).

to fall into the given range of errors in the measured $\mathrm{NO}_{2}$ concentrations. This finding strongly indicates that the $\mathrm{NO}_{x}$ and $\mathrm{NO}_{y}\left(=\mathrm{NO}_{x}, \mathrm{~N}_{2} \mathrm{O}_{5}, \mathrm{HONO}_{3}, \mathrm{HO}_{2} \mathrm{NO}_{2}\right.$, etc. $)$ budget and photochemistry of the LS, UT, and TTL are reproduced well in the TOMCAT/SLIMCAT simulations and that overall the $\mathrm{O}_{3}$-scaling technique works well for $\mathrm{NO}_{2}$.

Panels e in Figs. 3 to 8 compares measured and modeled $\mathrm{BrO}$. Again, measured and modeled $\mathrm{BrO}$ mixing ratios compare reasonably well for most flight sections, but sizable discrepancies are also discernible for some flight sections. Possible reasons for the latter are discussed in the following and may be due to deficits in the model's assumption regarding the sources of bromine (see Sect. 4.2) and/or deficits in the adopted photochemistry (see Sect. 4.4). 


\subsection{Comparison of measured and model organic bromine}

Before measured and modeled $\mathrm{BrO}$ can be compared quantitatively, it is necessary to compare the measured amounts of different brominated source gases with the model predictions (Fig. 10). For the assumed (constant) surface mixing ratios (see Sect. 2.7), measured and modeled $\mathrm{CH}_{3} \mathrm{Br}$ (upper left panel), $\mathrm{CHBr}_{3}$ (upper right panel), and all other halons, for example H1211 (lower right panel), compare well, even if the data are scattered from flight to flight. For $\mathrm{CH}_{2} \mathrm{Br}_{2}$, however, TOMCAT/SLIMCAT run no. 583 underpredicts the observed mixing ratio for high concentrations (by $0.1 \mathrm{ppt}$ ) and overpredicts it by up to $0.2 \mathrm{ppt}$ for low concentrations (lower left panel). This is most likely due to an assumed a surface concentration that is too low (1 ppt), variable mixing ratios at the surface not being correctly considered in the model, and/or errors in the atmospheric lifetime by reactions of $\mathrm{CH}_{2} \mathrm{Br}_{2}$ with $\mathrm{OH}$ radicals in the model (e.g., Mellouki et al., 1992; Ko et al., 2013; WMO, 2014).

The flight-to-flight and sample-to-sample scatter in $\mathrm{CH}_{3} \mathrm{Br}$ and $\mathrm{CHBr}_{3}$ is mostly due to different source regions of the air masses probed during SF1-2013 to SF6-2013. This implies a spatially (and possibly time-dependent) varying source strength of the brominated natural source gases (e.g., Hossaini et al., 2013; Ziska et al., 2013). In the present version of the TOMCAT/SLIMCAT simulations, this scatter introduces an estimated uncertainty of \pm 0.8 ppt into $\mathrm{Br}_{y}^{\mathrm{org}}$, and potentially into the inferred $\mathrm{Br}_{y}^{\text {inorg }}$ available in the TTL. The systematic underprediction of $0.1 \mathrm{ppt}$ at high $\mathrm{CH}_{2} \mathrm{Br}_{2}$ concentrations and its overly long lifetime in the TTL leading to $\mathrm{CH}_{2} \mathrm{Br}_{2}$ concentrations in the model that are too large for old air (by up to $0.2 \mathrm{ppt}$ ). Consequently, the model underpredicts $\mathrm{Br}_{y}^{\text {inorg }}$ by an additional $\leq 0.4 \mathrm{ppt}$. Both contributions to the uncertainty in the $\mathrm{Br}_{y}^{\text {org }}$ are considered when comparing measured and modeled $\mathrm{BrO}$ and $\mathrm{Br}_{y}^{\text {inorg }}$ (see below).

\subsection{Comparisons of measured $\mathrm{BrO}$ with previous studies}

Next, we compare our data with previous $\mathrm{BrO}$ measurements in the UT and TTL, i.e., the balloon measurements of Dorf et al. (2008) and the aircraft measurements of Wang et al. (2015) and Volkamer et al. (2015) during the Tropical Ocean tRoposphere Exchange of Reactive halogen species and Oxygenated VOC (TORERO) campaign.

Overall, the balloon-borne $\mathrm{BrO}$ profile measurements of Dorf et al. (2008) performed over tropical Brazil during the dry (i.e., the non-convective season) in June 2005 and June 2008 compare well with the $\mathrm{BrO}$ profiles inferred from our measurements for the UT and TTL (i.e., typically $[\mathrm{BrO}]=0.5-1.0 \mathrm{ppt}$ in the upper UT and base of the TTL, and up to $5 \mathrm{ppt}$ at the cold-point tropopause, e.g., compare Fig. 1 in Dorf et al., 2008, with Fig. 11 of the present study).

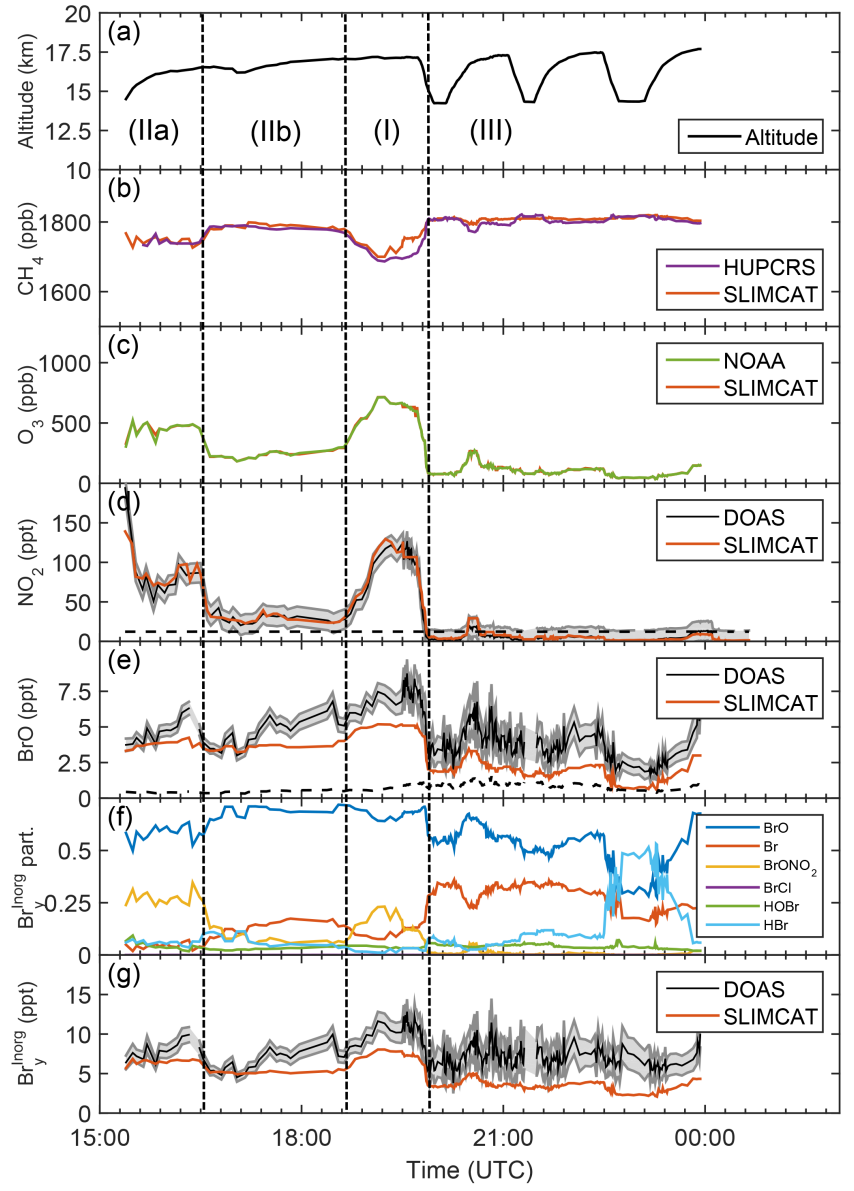

Figure 6. Same as Fig. 3 but for the research flight on 21-22 February 2013 (SF4-2013). Note that DOAS analysis of BrO for SF42013 is somewhat uncertain because the Fraunhofer reference spectra (taken via a diffuser) are affected by temporally changing residual structures likely due to ice deposits or some other residues on the entrance diffuser (see text).

The present study and the $\mathrm{BrO}$ profile measurement of Dorf et al. (2008) do not, however, confirm the recently reported presence of $\mathrm{BrO}$ of up to $3 \mathrm{ppt}$ in the tropical and subtropical UT and around the bottom of the TTL at $14 \mathrm{~km}$ (Wang et al., 2015; compare Fig. 2, panel a, in Wang et al., 2015, with left panel of Fig. 11 of the present study). Sensitivity studies using the BrO profile of Wang et al. (2015) as the a priori of an optimal-estimation concentration retrieval for the ATTREX measurements result in a kink of $\mathrm{BrO}$ around $12 \mathrm{~km}$ (Fig. 11). This behavior can be explained with the disagreement between the observed profiles above $13 \mathrm{~km}$ and the insensitivity of the ATTREX observation to $\mathrm{BrO}$ below this altitude.

While the geographical location of the observations by Wang et al. (2015) and those of the GH did not overlap, the ATTREX flights covered a wide geographic area over which we do not find indications of unexpectedly high or elevated $\mathrm{BrO}$ concentrations in the UT or TTL, either from inspecting 


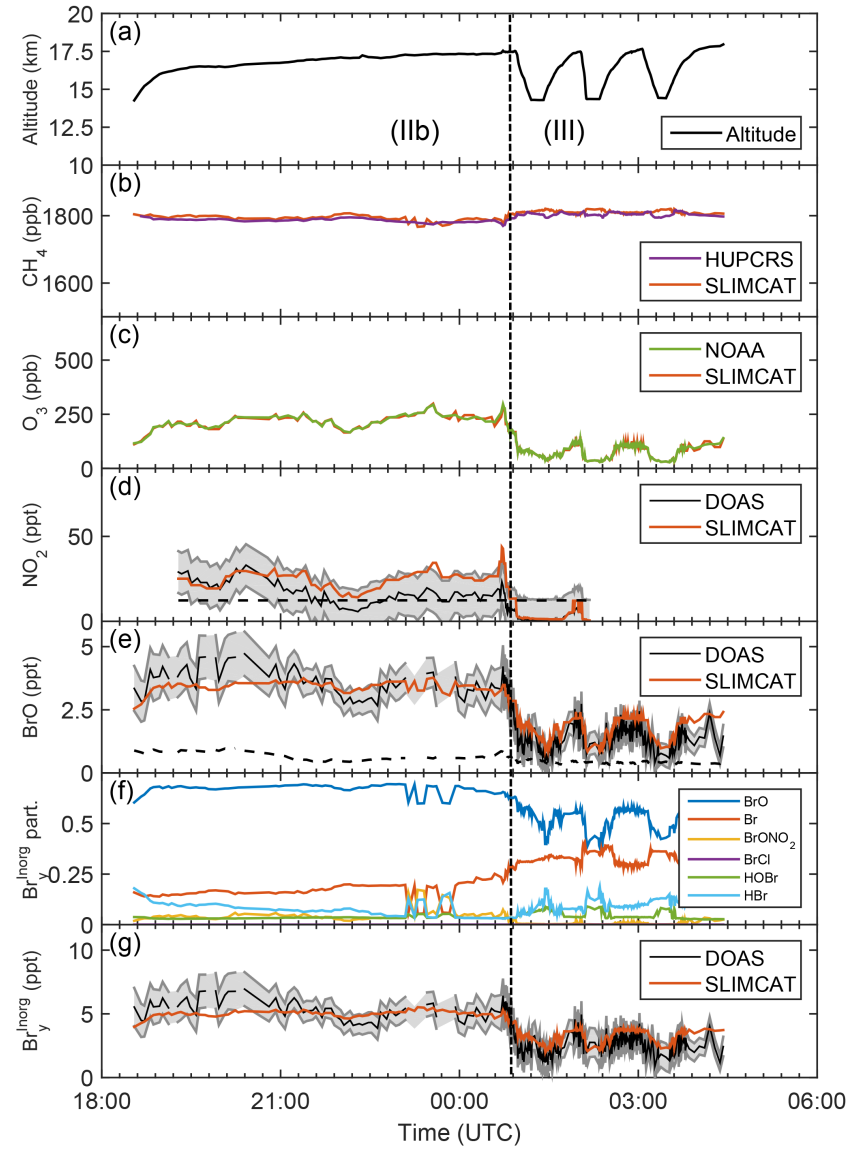

Figure 7. Same as Fig. 3 but for the research flight on 26-27 February 2013 (SF5-2013).

the UT from above (see, e.g., Fig. 15 in Stutz et al., 2016) or when directly probing the TTL (see Figs. 11 to 8).

Several similarities and differences exist between the TORERO measurements reported by Wang et al. (2015) and Volkamer et al. (2015) and our study. Using NSF/NCAR GV HIAPER (Gulfstream-V High-performance Instrumented Airborne Platform for Environmental Research), Wang et al. (2015) probed the UT and the bottom of the TTL (up to about $14 \mathrm{~km}$ ) for $\mathrm{BrO}$ over an adjacent part of the Pacific, i.e., mostly off the western coasts of South and Central America, the same season but in an area more to the south than that probed during the present study.

It is possible that the TORERO observations of Wang et al. (2015) and Volkamer et al. (2015) off the western coasts of South and Central America, i.e., further south than the ATTREX region but during the same season, encountered an unusual meteorological situation that would have caused downward transport of bromine-rich air from the lower stratosphere to the UT and the bottom of the TTL (up to about $14 \mathrm{~km}$ ) or that sea-salt-released bromine played a role (e.g., Schmidt et al., 2016).

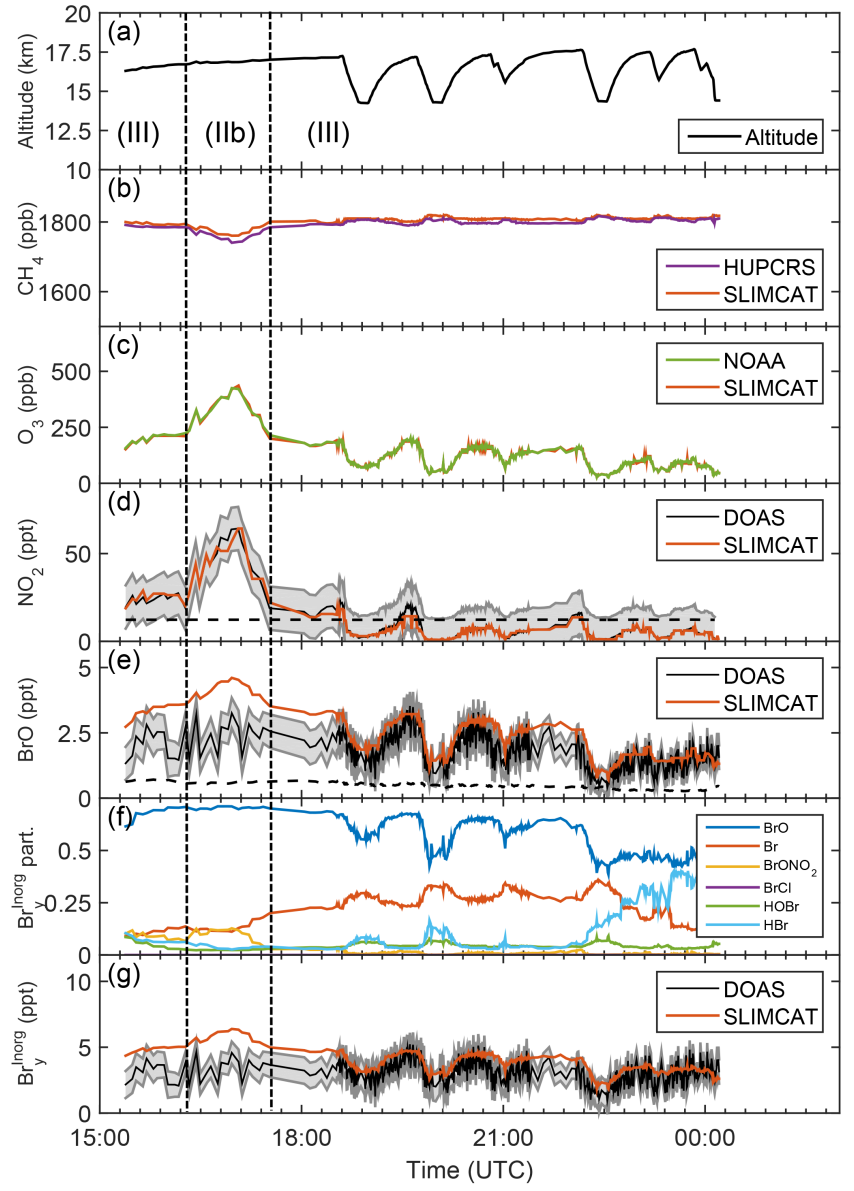

Figure 8. Same as Fig. 3 but for the research flight on 1-2 March 2013 (SF6-2013).
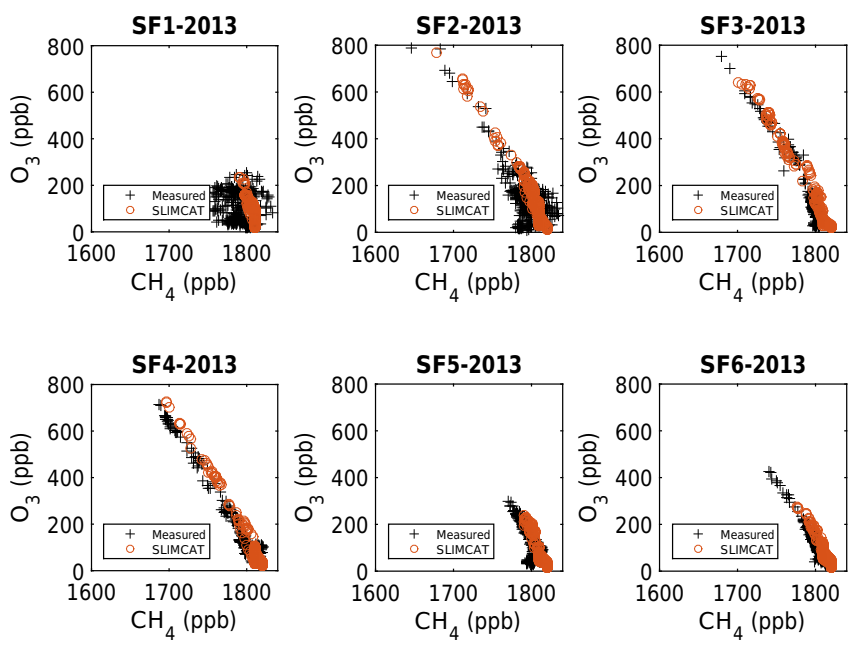

Figure 9. Correlation of observed $\mathrm{CH}_{4}$ (UCATS SF1-2013 and SF2-2013; HUPCRS SF3-2013 to SF6-2013) and $\mathrm{O}_{3}$ (NOAA) for the six NASA-ATTREX science flights in 2013. Also shown are the corresponding correlations from the TOMCAT/SLIMCAT simulation. 

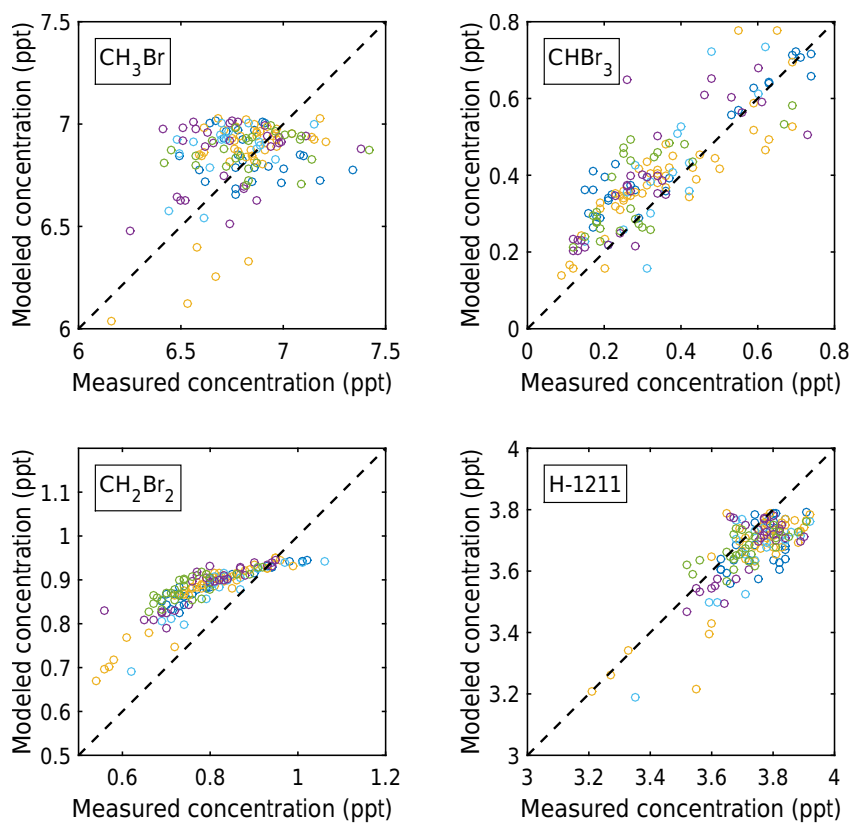

Figure 10. Correlation of GWAS measured and TOMCAT/SLIMCAT modeled major brominated source gases. Upper left panel for $\mathrm{CHBr}_{3}$, upper right panel for $\mathrm{CHBr}_{3}$, lower left panel for $\mathrm{CH}_{2} \mathrm{Br}_{2}$, and lower right panel for halon-1211. The concentrations for different flights are color-coded: SF1-2013 in blue, SF3-2013 in yellow, SF4-2013 in light blue, SF5-2013 in purple, and SF6-2013 in green.

However, our study has identified possible problems when using an optimal-estimation technique with constraints based, for example, on measured $\mathrm{O}_{2}-\mathrm{O}_{2}$ for high altitude aircraft limb observations. The RT below the aircraft and in particular in the lower troposphere plays a crucial role for the observations due to the much higher $\mathrm{O}_{2}-\mathrm{O}_{2}$ concentrations. Also since individual limb measurements already cover an area of typically $\sim 200 \times 20 \mathrm{~km}$ in front of the aircraft (see Fig. 5 in Stutz et al., 2016) and even more crucially when applying optimal estimation for profile inversion, a series of measurements taken during the ascent and descent of the $\mathrm{GH}$ are jointly inverted. Hence the radiative field and its time dependence need to be known over a larger footprint (i.e., the RT is 2-D, or even 3-D plus its time dependence over the period of single profile measurement).

We did not encounter conditions without (marine stratus cumulus) clouds in this footprint during any of the ATTREX flights. Therefore, any skylight analyzed for the $\mathrm{O}_{2}-\mathrm{O}_{2}$ absorption in the limb direction may carry additional or even substantial information on the radiative transfer of loweratmospheric layers (see Fig. 7 in Stutz et al., 2016) rather than of the targeted atmospheric layers. We acknowledge that Wang et al. (2015) and Volkamer et al. (2015) selected "cloud-free" conditions at the location of their profile measurement, but the cloudiness in the large area ahead of their aircraft is less clear.
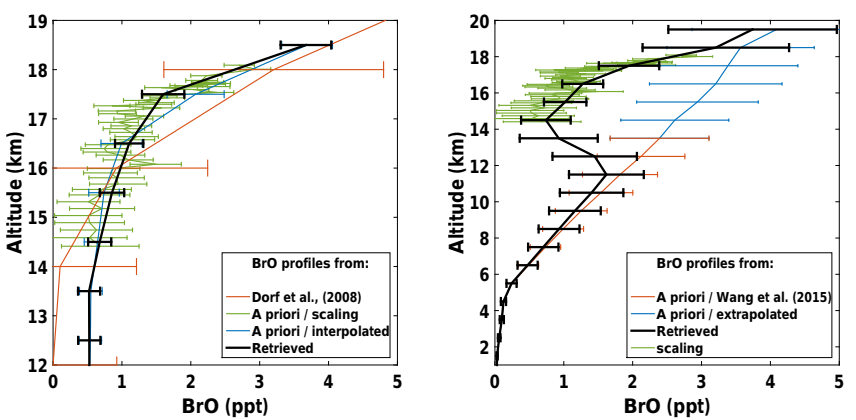

Figure 11. Comparison of the inferred $\mathrm{BrO}$ profile for the ascent after dive no. 2 of the flight on 5-6 February 2013 with previously published (modeled and measured) $\mathrm{BrO}$ profiles. Please note the different altitude ranges in the two panels. $\mathrm{BrO}$ profiles retrieved using the optimal-estimation method are shown in black and those using the $\mathrm{O}_{3}$-scaling technique are shown by green symbols, error bars, and lines. In the two panels, different a priori information is used to constrain the optimal-estimation retrieval. Left panel: TOMCAT/SLIMCAT model predictions are used as a priori (blue). Also shown for comparison is the $\mathrm{BrO}$ profile published by Dorf et al. (2008), which was measured over northeastern Brazil in June 2005 (red). Right panel: the $\mathrm{BrO}$ profile of Wang et al. (2015) (red) and its extrapolation to $20 \mathrm{~km}$ (blue) are used as a priori in the optimal estimation. The kink in the retrieved BrO profile (black) at about $12 \mathrm{~km}$ strongly indicates that the $\mathrm{BrO}$ profile of Wang et al. (2015) is neither compatible with the $\mathrm{BrO}$ profiles inferred using the $\mathrm{O}_{3}$ scaling technique (green) nor those obtained from optimal estimation (black) (for further details, see Sect. 4.3).

Another challenge we encountered was that of the overhead $\mathrm{BrO}$ column, which can substantially contribute to the limb $\mathrm{BrO}$ signal. The large concentrations of $\mathrm{BrO}$ in the stratosphere during the daytime and its potential column changes mostly due to a changing tropopause height or intrusion of tropospheric air (e.g., at the subtropical or polar jet) may thus mimic the presence of $\mathrm{BrO}$ in the limb direction or at the flight altitude (e.g., Wang et al., 2015, and Volkamer et al., 2015, and Fig. 14 in Stutz et al., 2016). We solved this problem by using a highly resolved stratospheric CTM to study the potential influence of changing overhead $\mathrm{BrO}$ concentrations on our results.

In conclusion, our sensitivity studies have shown a potential problem with the $\mathrm{O}_{2}-\mathrm{O}_{2}$ constrained RT calculations used to retrieve vertical $\mathrm{BrO}$ profiles as well as the need to accurately determine the stratospheric $\mathrm{BrO}$ column. With this in mind and the disagreement between our upper-troposphere-lower-stratosphere (UTLS) $\mathrm{BrO}$ profiles and TORERO flights 12 and 17 (Wang et al., 2015 and Volkamer et al., 2015), it is clear that future work is needed in reconciling the observations as well as the different retrieval approaches. 

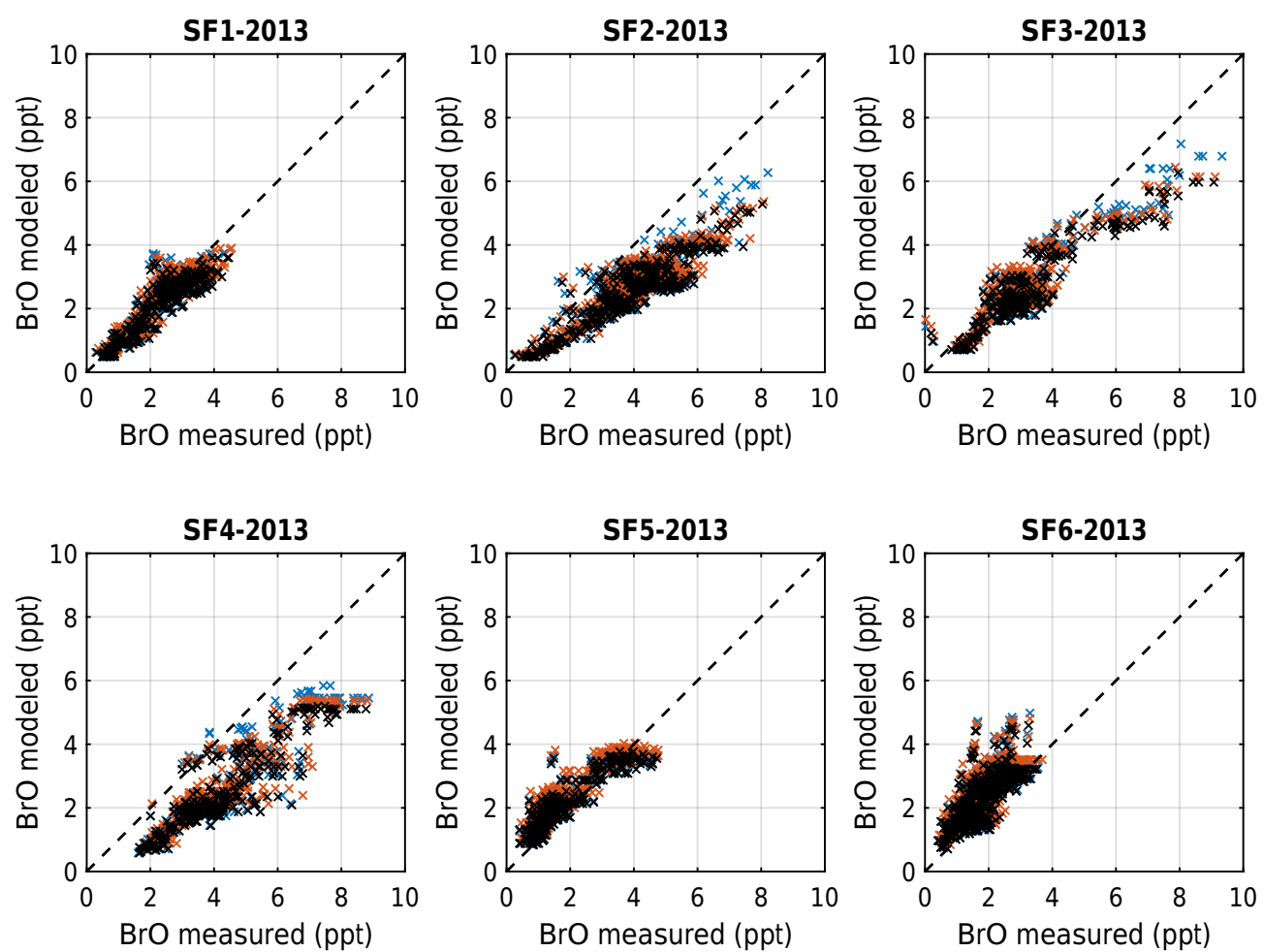

Figure 12. Comparison of measured and modeled BrO for the NASA-ATTREX science flights 1 to 6 in 2013. Black crosses are for model run no. 583, blue crosses for no. 584, and red crosses for no. 585 .

\subsection{Comparison of measured and modeled BrO}

Measured and modeled $\mathrm{BrO}$ are displayed in Figs. 3 to 8 (panel e) together with the modeled $\mathrm{Br}_{y}^{\text {inorg }}$ partitioning (panel f) and inferred $\mathrm{Br}_{y}^{\text {inorg }}$ (panel g). Elevated $\mathrm{BrO}$ concentrations are measured within the LS (range 3-9 ppt), and lower $\mathrm{BrO}$ concentrations are measured in the TTL (range $0.5-5 \mathrm{ppt})$, with the smallest $\mathrm{BrO}$ concentrations $(0.5-1 \mathrm{ppt})$ occurring near the bottom of the TTL. Overall, this behavior is expected from arguments based on the amount and composition of the brominated organic and inorganic source gases, their lifetimes, atmospheric transport, and photochemistry (e.g., Fueglistaler et al., 2009; Aschmann et al., 2009; Hossaini et al., 2012b; Ashfold et al., 2012; WMO, 2014; Fernandez et al., 2014; Saiz-Lopez and Fernandez, 2016). In particular, for our daytime measurements, it is observed that (a) $\mathrm{BrO}$ increases with $\mathrm{O}_{3}$ and available $\mathrm{Br}_{y}^{\text {inorg }}$ and thus altitude and (b) the predicted $\mathrm{BrO} / \mathrm{Br}_{y}^{\text {inorg }}$ ratio decreases towards the bottom of the TTL, where (c) $\mathrm{HBr}$ and/or $\mathrm{Br}$ atoms may become comparable to $\mathrm{BrO}$, but $\mathrm{HOBr}$ does not play a major role in the $\mathrm{Br}_{y}^{\text {inorg }}$ partitioning. While observation (a) is due to the increased destruction of primarily the short-lived $\mathrm{Br}_{y}^{\text {org }}$ species and the efficient reaction of the released $\mathrm{Br}$ atoms with increasing altitude and increasing ozone concentrations, observations (b) and (c) are due to reactions of the $\mathrm{Br}$ atoms with $\mathrm{CH}_{2} \mathrm{O}$ (and less $\mathrm{H}_{2} \mathrm{O}_{2}$ ) into $\mathrm{HBr}$, which is recycled back by reactions with $\mathrm{OH}$ and by variable amounts heterogeneously (depending on the available surface of aerosols and cloud particles) to $\mathrm{Br}$ atoms, as predicted by Fernandez et al. (2014), and Saiz-Lopez and Fernandez (2016). The predicted minor role of HOBr eventually formed by reactions of $\mathrm{OH}$ radicals with heterogeneously produced $\mathrm{Br}_{2}$ or by the reaction $\mathrm{HO}_{2}+\mathrm{BrO}$ and photolytic destruction of $\mathrm{HOBr}$ in the TTL is also noteworthy. While the rate of the former reaction is small due to the short photolytic lifetime of $\mathrm{Br}_{2}$ anyway, the rate of the latter reaction is small due to the small OH concentration in the TTL as compared to photolysis of $\mathrm{HOBr}$ during the daytime.

Figure 12 compares measured and modeled $\mathrm{BrO}$. For the majority of all flights (except flight SF4-2014, for which a DOAS retrieval problem exists which causes a constant bias of about 2 ppt in inferred $\mathrm{BrO}$ ), measured and modeled $\mathrm{BrO}$ closely compare for low concentrations (i.e., close to the bottom to the TTL) or are comparable younger air based on measured $\mathrm{CH}_{4}$. For larger $\mathrm{BrO}$ concentrations (and older air), good agreement between the measurement and model is found for SF1-2013, SF5-2013, and SF6-2013 when air of low $\mathrm{NO}_{2}$ concentrations (and predicted low $\mathrm{BrONO}_{2}$ concentrations) is usually probed. For large $\mathrm{BrO}$ concentrations as encountered during flights SF2-2013 and SF3-2013, the measured $\mathrm{BrO}$ is up to $2 \mathrm{ppt}$ or $25 \%$ larger than what the model predicts. This gap could partly be closed by adjusting the $\mathrm{CH}_{2} \mathrm{Br}_{2}$ surface concentration and atmospheric lifetime 
or by considering a detailed scheme for the dehalogenation of sea salt, i.e., bromine activation (e.g., Saiz-Lopez et al., 2004; Fernandez et al., 2014; Schmidt et al., 2016). Adjusting $\mathrm{CH}_{2} \mathrm{Br}_{2}$ would add $0.4 \mathrm{ppt}$ of $\mathrm{Br}_{y}^{\text {inorg }}$ or $\sim 0.3 \mathrm{ppt}$ to $\mathrm{BrO}$, thus removing the flight-to-flight scatter in source gas concentrations $( \pm 0.8 \mathrm{ppt})$ in $\mathrm{Br}_{y}^{\text {inorg }}$. This could for example be done by a detailed back trajectory and source appointment analysis, to which a forthcoming study will be devoted. Likewise, the dehalogenation of sea salt could add another $0.5 \mathrm{ppt}$ to $\mathrm{BrO}$ (or about 0.7 ppt of $\mathrm{Br}_{y}^{\text {inorg }}$ ) in the upper TTL (e.g., Saiz-Lopez et al., 2004; Fernandez et al., 2014; Schmidt et al., 2016).

\subsection{Uncertainties in estimating the inorganic bromine partitioning}

Another reason for the gap in measured and modeled $\mathrm{BrO}$ may come from uncertainties in the kinetic constants used and how they affect the $\mathrm{Br}_{y}^{\text {inorg }}\left(=\mathrm{Br}+2 \cdot \mathrm{Br}_{2}+\mathrm{BrO}+\right.$ $\mathrm{BrONO}_{2}+\mathrm{HOBr}+\mathrm{HBr}+\mathrm{BrCl}$ ) partitioning. Our photochemical modeling, aimed at reproducing measured $\mathrm{O}_{3}$, $\mathrm{NO}_{2}$, and $\mathrm{BrO}$ (see the panels $\mathrm{f}$ in Figs. 3 to 8), indicates that during the daytime $\mathrm{HOBr}$ and $\mathrm{HBr}$ contribute less than $10 \%$ to $\mathrm{Br}_{y}^{\text {inorg }}$. Therefore, we concentrate on the photochemical model errors due to the partitioning primarily among $\mathrm{BrO}$, $\mathrm{Br}$, and $\mathrm{BrONO}_{2}$. In this context, the reactions $\mathrm{BrO}+\mathrm{NO}_{2}$ $+\mathrm{M} \rightarrow \mathrm{BrONO}_{2}+\mathrm{M}$ are the most important, followed by the photolysis of $\mathrm{BrONO}_{2}$ and the reaction $\mathrm{Br}+\mathrm{O}_{3} \rightarrow \mathrm{BrO}$ $+\mathrm{O}_{2}$.

How uncertainties of the photolytic destruction $(J)$ and three-body formation reaction ( $k$; together referred to as $J / k$ ) of $\mathrm{BrONO}_{2}$ propagate into $\mathrm{BrO}$ is tested in model run no. 584. Here, according to the finding of Kreycy et al. (2013), $J / k$ was increased by a factor $1.7(+0.4 /-0.2)$ as compared to the Jet Propulsion Laboratory (JPL) recommendation (Sander et al., 2011) (see the blue crosses in Fig. 12). Evidently, increasing $J / k$ helps to close the remaining gap in measured versus modeled $\mathrm{BrO}$, which becomes particularly relevant to reproducing $\mathrm{BrO}$ when $\mathrm{NO}_{2}$ is large, i.e., in the subtropical LS.

Furthermore, Sander et al. (2011) estimate the uncertainty in the reaction rate coefficient $\mathrm{k}_{\mathrm{Br}+\mathrm{O} 3}$ at low temperature ( $T=190 \mathrm{~K}$ ) to be $\pm 40 \%$ (see comment G31). When only considering the two studies which actually measured rather than extrapolated the reaction rate coefficient into the relevant temperature range $(T=190-200 \mathrm{~K})$, a smaller uncertainty $(28 \%)$ is indicated (Michael et al., 1978, and Nicovich et al., 1990). Therefore, in the following, an uncertainty of $28 \%$ for $\mathrm{k}_{\mathrm{Br}+\mathrm{O} 3}$ is assumed. Overall, increasing $k_{\mathrm{Br}+\mathrm{O} 3}$ (model run no. 585) to the upper limit possible according to the JPL compilation (i.e., by factor of 1.28) changes the measured vs. modeled correlation for BrO very little (see the red crosses in Fig. 12). It does, however, change the $\mathrm{Br}_{y}^{\text {inorg }}$ partitioning so that [BrO] is always largely prevalent over $[\mathrm{Br}]$ even at the lowest altitudes of the TTL (see, e.g., panel $\mathrm{f}$ in Figs. 3 to 8). Our joint measurement of $\mathrm{O}_{3}$, $\mathrm{NO}_{2}$, and $\mathrm{BrO}$ and the supporting CTM simulations thus indicate $[\mathrm{Br}] /[\mathrm{BrO}]<1$ for all probed regimes. Our finding is therefore in contrast to the simulations of Fernandez et al. (2014) and Saiz-Lopez and Fernandez (2016), who suggest that $[\mathrm{Br}] /[\mathrm{BrO}]$ may become larger than unity in the tropical UT and TTL during the daytime. This conclusion is due mostly to the measured $\mathrm{O}_{3}$ concentrations, which are larger than those modeled in the study of Fernandez et al. (2014) and Saiz-Lopez and Fernandez (2016), and the conclusion is irrespective of what (within the given error bars) is assumed for $k_{\mathrm{Br}+\mathrm{O} 3}$.

Gaussian addition of all uncertainties and errors (i.e., the errors of the retrieved BrO concentrations (in Sect. 4.4 of Stutz et al., 2016), the cross section error, and the uncertainty in the modeled $[\mathrm{Br}] /[\mathrm{BrO}]$ and $\left[\mathrm{BrONO}_{2}\right] /[\mathrm{BrO}]$ ratios) leads to the $\mathrm{Br}_{y}^{\text {inorg }}$ error, as indicated in panel $\mathrm{f}$ of Figs. 3 to 8 .

\subsection{Inferred total $\mathrm{Br}_{y}^{\text {inorg }}$}

Finally, we discuss the inferred $\mathrm{Br}_{y}^{\text {inorg }}$ (contribution 4) as a function of potential temperature in the LS, UT, and TTL over the eastern Pacific during the 2013 convective season (Fig. 13). Here we discriminate between young-air $\left[\mathrm{CH}_{4}\right] \geq 1790 \mathrm{ppb}$, mostly found within the tropical UT and TTL (Fig. 13, left panel), and older-air $\left[\mathrm{CH}_{4}\right] \leq 1790 \mathrm{ppb}$ (Fig. 13, right panel), mostly found in the subtropical lowermost stratosphere. The different histograms in Fig. 13 clearly indicate that $\mathrm{Br}_{y}{ }^{\text {inorg }}$ increases with increasing potential temperature, i.e., from $2.63 \pm 1.04 \mathrm{ppt}$ at $\theta=350-360 \mathrm{~K}$ (at the bottom of the TTL) to $4.22 \pm 1.37 \mathrm{ppt}$ for $\theta=390-400 \mathrm{~K}$ (just above the cold-point tropopause). The inferred $\mathrm{Br}_{y}^{\text {inorg }}$ thus brackets the modeled $\left[\mathrm{Br}_{y}^{\text {inorg }}\right]=3.02 \pm 1.90 \mathrm{ppt}$ predicted to exist at $17 \mathrm{~km}$ in the TTL well (Navarro et al., 2015).

The increase in $\operatorname{Br}_{y}^{\text {inorg }}$ with increasing potential temperature $\theta$ and decreasing $\mathrm{CH}_{4}$ concentration thus reflects the decrease in concentrations of brominated VSLS (contribution 3 ). The correspondence of decreasing $\mathrm{Br}_{y}^{\text {org }}$ with increasing $\mathrm{Br}_{y}$ inorg concentrations is also found on a sample-to-sample as well as on a flight-to-flight basis. This correspondence keeps $\left[\mathrm{Br}_{y}\right]$ almost constant within the TTL during an individual flight, but $\left[\mathrm{Br}_{y}\right]$ varies from flight to flight in a range of $\left[\mathrm{Br}_{y}\right]=20.3$ ppt to 22.3 ppt (Fig. 14).

Moreover, it appears that the increase in $\operatorname{Br}_{y}^{\text {inorg }}$ with $\theta$ mostly corresponds to a decrease in concentrations of the brominated VSLS if only the same (young) air masses of large $\mathrm{CH}_{4}$ concentrations are probed (Fig. 15). For example for SF1-2013, SF5-2013, and SF6-2013 when mostly air masses of the TTL are probed, all data points fall into a band of about \pm 1 ppt in width, next to a flight-dependent diagonal line (not shown), but this is not the case for SF3-2013 when air masses of the LS (and thus older air) and TTL are probed. 

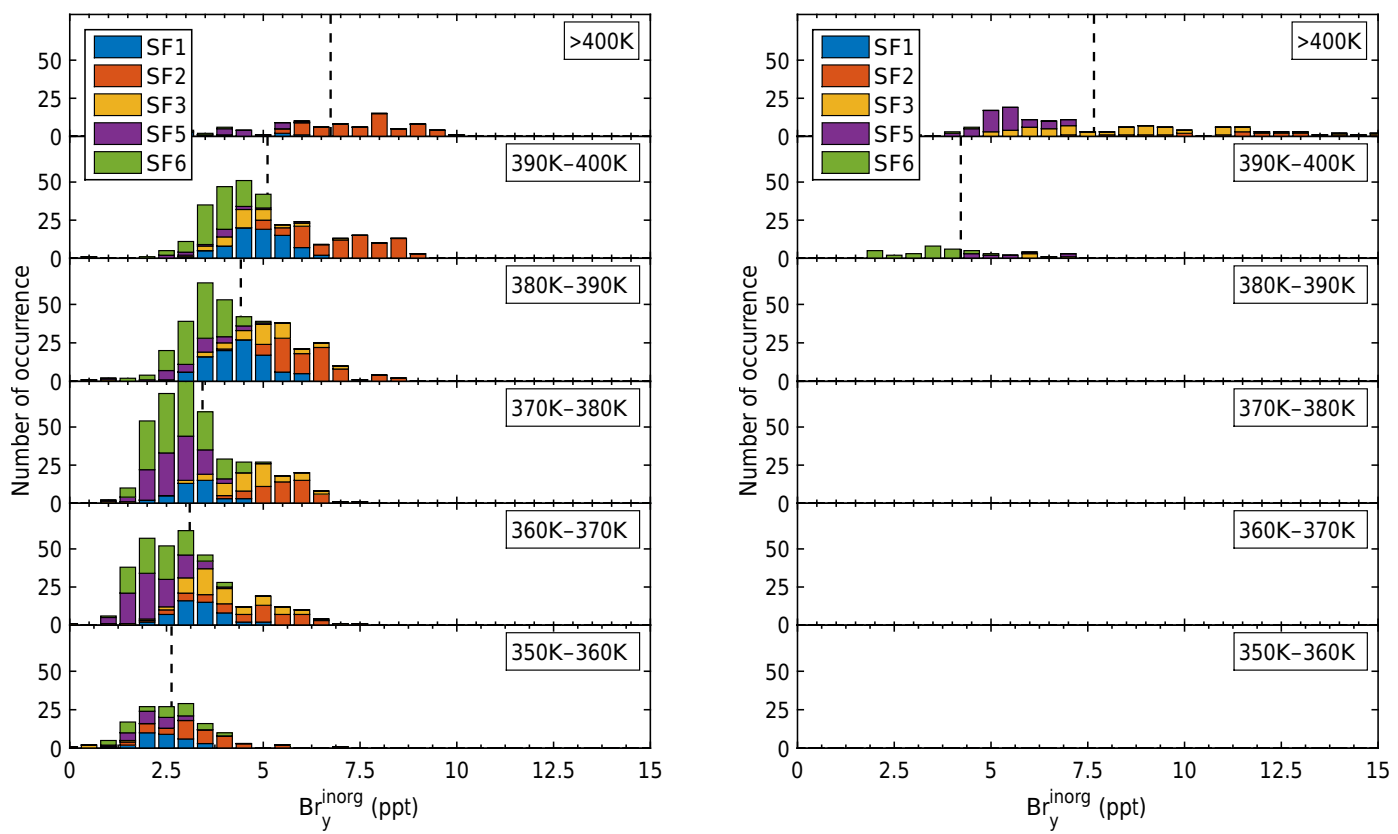

Figure 13. Histogram of $\mathrm{Br}_{y}^{\text {inorg }}$ occurrence as a function of potential temperature for $\left[\mathrm{CH}_{4}\right] \geq 1790 \mathrm{ppb}(\mathrm{left}$ panel) and $[\mathrm{CH} 4] \leq 1790 \mathrm{ppb}$ (right panel). High $\left[\mathrm{CH}_{4}\right]$ can be considered as a marker for young air mostly found in the freshly ventilated TTL, while low [CH 4$]$ can be considered as a marker for aged air mostly found in the subtropical lowermost stratosphere. The mean and the variance of $\mathrm{Br}_{y} \mathrm{inorg}_{\mathrm{for}} \mathrm{young}$ air (left panel) are for $\theta=350-360 \mathrm{~K}, 2.63 \pm 1.04 \mathrm{ppt} ; \theta=360-370 \mathrm{~K}, 3.1 \pm 1.28 \mathrm{ppt} ; \theta=370-380 \mathrm{~K}, 3.43 \pm 1.25 \mathrm{ppt} ; \theta=380-390 \mathrm{~K}$, $4.42 \pm 1.35 \mathrm{ppt} ; \theta=390-400 \mathrm{~K}, 5.1 \pm 1.57 \mathrm{ppt}$, and $\theta \geq 400 \mathrm{~K}, 6.74 \pm 1.79 \mathrm{ppt}$. Aged air (right panel): for $\theta=390-400 \mathrm{~K}, 4.22 \pm 1.37 \mathrm{ppt}$; and $\theta \geq 400 \mathrm{~K}, 7.67 \pm 2.72 \mathrm{ppt}$.

When extrapolating the data points along lines of constant [VSLS $]+\left[\mathrm{Br}_{y}^{\text {inorg }}\right]$ bromine (grey dashed lines in Fig. 15) for SF1-2013, SF5-2013, and SF6-2013 to [Br $\left.{ }_{y}^{\text {inorg }}\right]=0$ and assuming no bromine is effectively lost in the troposphere, then the apparent concentrations of brominated VSLS at the surface should range between 4 and 8.5 ppt. However, larger concentrations of brominated VSLS (some $10 \mathrm{ppt}$ ) are frequently measured in the boundary layer of the Pacific (e.g., Yokouchi et al., 1997; Schauffler et al., 1998; Wamsley et al., 1998; Yokouchi et al., 2005; Tegtmeier et al., 2012; Ashfold et al., 2012; Ziska et al., 2013; Sala et al., 2014). Further, bromine released from sea salt also contributes to $\mathrm{Br}_{y}^{\text {inorg }}$ in the marine boundary layer and may reach the bottom of the TTL in variable amounts (e.g., Saiz-Lopez et al., 2004; Fernandez et al., 2014; Schmidt et al., 2016). Therefore, effective loss processes for inorganic bromine, for example by the heterogeneous uptake of inorganic bromine on aerosol and cloud particles, must be active in the atmosphere (e.g., Schmidt et al., 2016).

Next, when subtracting the almost constant contribution of $\mathrm{CH}_{3} \mathrm{Br}$ and the halons to total stratospheric bromine (14.6 ppt in 2013) from the range (20.3 to $22.3 \mathrm{ppt}$ ) of total $\mathrm{Br}_{y}$ given, a variable contribution from VSLS bromine (contribution 3 ) and $\mathrm{Br}_{y}^{\text {inorg }}$ (contribution 4) to total TTL bromine in the range of $5.7 \mathrm{ppt}$ to $7.7 \mathrm{ppt}( \pm 1.5 \mathrm{ppt}$ ) is calculated (Fig. 15). We note that this range falls well into the range assessed in WMO
(2014) and recently estimated by Navarro et al. (2015) (6 ppt; range $=4-9 \mathrm{ppt}$ ) for contribution of 3 and 4 to the total stratospheric $\mathrm{Br}_{y}$. It is, however, somewhat (up to $2 \mathrm{ppt}$ ) larger than indicated in earlier work, including our balloon-borne studies (for details, see Sect. 1).

Here one may wonder whether (a) this result is significant, (b) some $\mathrm{Br}_{y}^{\text {inorg }}$ is actually removed by heterogeneous processes in the TTL (e.g., Aschmann et al., 2011; Aschmann and Sinnhuber, 2013), or (c) TTL $\mathrm{Br}_{y}$ shows some seasonality analogous to the "tape recorder" for $\mathrm{H}_{2} \mathrm{O}$ (e.g., Levine et al., 2008; Krüger et al., 2008; Fueglistaler et al., 2009; Schofield et al., 2011; Ploeger et al., 2011).

The non-negligible amounts of $\mathrm{Br}_{y}^{\text {inorg }}(2.63 \pm 1.04) \mathrm{ppt}$ are also remarkable and range from 0.5 to $5.25 \mathrm{ppt}$, which is from close to 0 to $25 \%$ of all TTL bromine inferred for altitudes at the bottom of the TTL $(\theta=350-360 \mathrm{~K})$, of which 40 to $50 \%$ may consist of $\mathrm{BrO}$. This finding clearly sets a range and an upper limit for the $\mathrm{Br}_{y}^{\text {inorg }}$ influx into the TTL due to entrained air masses of recent tropospheric origin (contribution 4). Again, the latter can most likely be attributed to different source regions (and thus emission strengths) of the brominated VSLS and bromine released from sea salt and a varying degree of photochemical and heterogeneous processing of the air masses transported from the surface to the TTL. The increase in variance found for $\mathrm{Br}_{y}^{\text {inorg }}$, which increases in absolute terms but decreases in relative terms (i.e., 

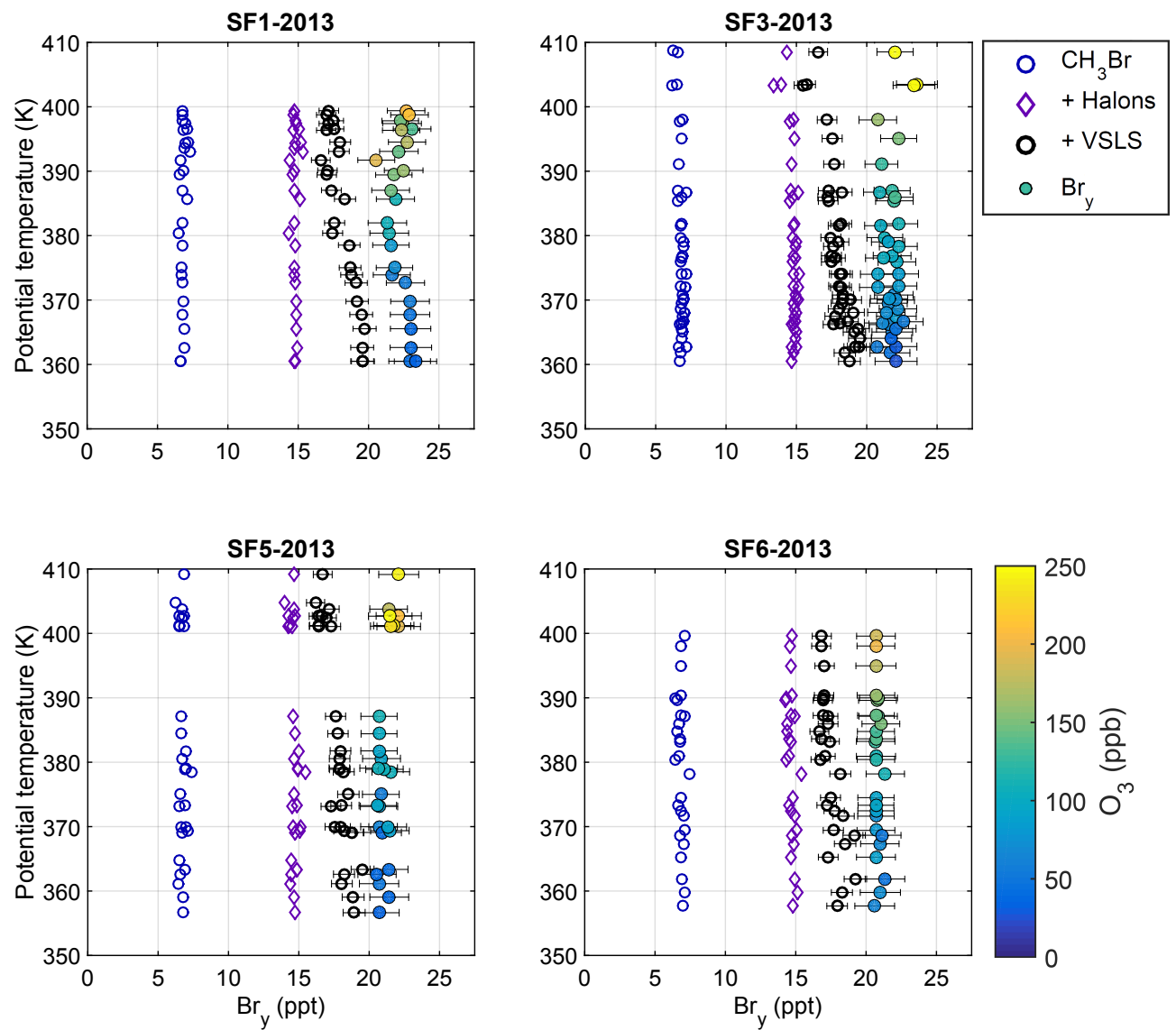

Figure 14. $\operatorname{Br}_{y}$ as a function of potential temperature $(\theta)$ for all dives during the 2013 NASA-ATTREX flights when joint measurements of $\mathrm{Br}_{y}^{\text {org }}$ and $\mathrm{Br}_{y}^{\text {inorg }}$ are available.

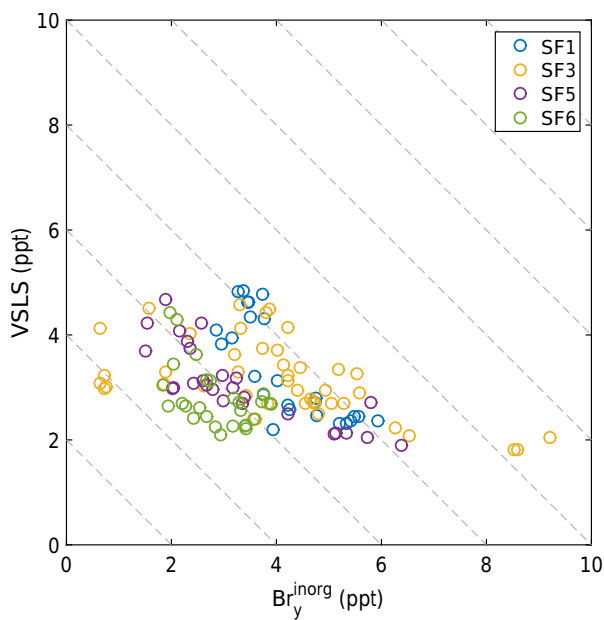

Figure 15. $\operatorname{Br}_{y}^{\text {inorg }}$ as a function of the sum of all brominated VSLS using the same color code as in Fig. 10. If all $\mathrm{Br}_{y}^{\text {inorg }}$ resulted from destroyed VSL bromine of the same air mass from near the surface, then all data points should follow individual diagonal lines. from 0.4 for $\theta$ in the range 350 to $360 \mathrm{~K}$ to 0.3 for $\theta=390$ to $400 \mathrm{~K}$ ) with increasing $\theta$, is also noteworthy. This may indicate a subsequent flattening-out of the air-mass-to-air-mass variability of $\mathrm{Br}_{y}^{\text {inorg }}$ in aging air due to the photochemical decay of the brominated organic source gases and atmospheric mixing processes.

\subsection{Implications for ozone}

The ozone budget in the TOMCAT/SLIMCAT simulation has been analyzed based on the rate-limiting steps of the catalytic ozone destruction cycles, according to the concept of Johnston and Podolske (1978). The chemical rates are averaged over the eastern Pacific region $\left(20^{\circ} \mathrm{S}-20^{\circ} \mathrm{N}, 170-90^{\circ} \mathrm{W}\right)$ for the duration of the campaign. Within this domain, the net rate of ozone change varied from a loss of $-0.3 \mathrm{ppbv}^{-1} \mathrm{day}^{-1}$ at the base of the TTL $(\theta=355 \mathrm{~K}, p=150 \mathrm{hPa})$ to a production of $+1.8 \mathrm{ppbv}^{-1 a y^{-1}}$ at the top $(\theta=383 \mathrm{~K}, p=90 \mathrm{hPa})$. This increase in $\mathrm{O}_{3}$ with height is due to the strong vertical gradient in the production rate of odd oxygen by $\mathrm{O}_{2}$ photolysis. Within the catalytic ozone loss cycles in the TTL, the model indicates that those containing bromine contribute between $12 \%$ (base of TTL) and 22\% (top of TTL) of the total 
(see Appendix Sect. A). The dominant contribution to this is through the cycle involving $\mathrm{BrO}+\mathrm{HO}_{2}$ to form $\mathrm{HOBr}$. Overall, the modeled ozone loss cycles which account for the majority of the destruction in this region are those with the rate-limiting steps of the reaction $\mathrm{HO}_{2}+\mathrm{O}_{3}$ to form $\mathrm{OH}+2 \mathrm{O}_{2}$ and the reaction of $\mathrm{HO}_{2}+\mathrm{HO}_{2}$ to form $\mathrm{H}_{2} \mathrm{O}_{2}$, i.e., cycles involving $\mathrm{HO}_{x}$ species. Therefore, increases in the bromine loading of the TTL caused by possible or expected increases have the potential to deplete ozone in a region where ozone changes have the largest impact on radiative forcing (Riese et al., 2012).

Quantifying the radiative impact of the $\mathrm{O}_{3}$ changes described above is the beyond the scope of this study. However, we can note that (i) recent work has highlighted the efficiency of brominated VSLSs at influencing climate (through changed $\mathrm{O}_{3}$ ), owing to their efficient breakdown in the UTLS (Hossaini et al., 2015), and (ii) a significant increase in $\mathrm{Br}_{y}$ in this region (from VSLS or other sources) could be important for future climate forcing. The latter could conceivably occur given suggested climate-induced changes to (1) tropospheric transport (e.g., Hossaini et al., 2012b), (2) changes in OH, affecting VSLS lifetimes (Schäfer et al., 2016), (3) and/or an elevated bromine loading in the UT-LS and TTL due to the expected increase in VSLS emissions from the rapidly growing aquaculture industry (WMO, 2014).

\section{Conclusions}

The subtropical lowermost stratosphere, upper troposphere, and tropopause layer of the eastern Pacific are probed for inorganic bromine during the convective season (February and March 2013). The measurements of $\mathrm{CH}_{4}, \mathrm{O}_{3}, \mathrm{NO}_{2}, \mathrm{BrO}$, and some important organic brominated source gases are intercompared with TOMCAT/SLIMCAT simulations. After the simulated TOMCAT/SLIMCAT curtains of $\mathrm{O}_{3}$ are projected onto the measured $\mathrm{O}_{3}$ concentrations, measured and modeled $\mathrm{CH}_{4}$ agree well. This agreement is not surprising since $\mathrm{O}_{3}$, and $\mathrm{CH}_{4}$ are strongly anticorrelated (see Fig. 9). It thus provides evidence that the relevant dynamical processes are represented well in the TOMCAT/SLIMCAT simulations. When the simulated curtains of $\mathrm{NO}_{2}$ are adjusted with the same parameters as inferred above, excellent agreement is again found between measured and modeled $\mathrm{NO}_{2}$, thus providing further confidence in our measurement technique, in the modeled $\mathrm{NO}_{y}$ photochemistry, and in our overall approach.

The measured and modeled TTL concentrations of $\mathrm{CH}_{2} \mathrm{Br}_{2}$ and $\mathrm{CHBr}_{3}$ are found to compare reasonably well to the surface concentrations and atmospheric lifetimes of both species adopted in the model $\left(\left[\mathrm{CHBr}_{3}\right]=1.4 \mathrm{ppt},\left[\mathrm{CH}_{2} \mathrm{Br}_{2}\right]=1 \mathrm{ppt}\right.$ at the surface). Further, the contribution to bromine in the LS, UT, and TTL by some other VSLS chloro-bromo-hydrocabrons ( $\Sigma$ $\left[\mathrm{CHClBr}_{2}, \mathrm{CHCl}_{2} \mathrm{Br}, \mathrm{CH}_{2} \mathrm{ClBr}\right.$, etc.]) is accounted for by assuming a constant surface concentration of $1 \mathrm{ppt}$ in the model. Flight-to-flight total organic bromine inferred from these VSLS species is found to vary by $\pm 1 \mathrm{ppt}$ in the TTL over the eastern Pacific in early 2013, which clearly indicates different origins and possibly atmospheric processing of the investigated air masses.

The measured $\mathrm{BrO}$ concentrations range between 3 and $9 \mathrm{ppt}$ in the subtropical LS. In the TTL they range between $0.5 \pm 0.5 \mathrm{ppt}$ at the bottom of the TTL and about $5 \mathrm{ppt}$ at $\theta=400 \mathrm{~K}$, in overall good agreement with the model simulations and the expectation based on the decay of the brominated source gases and atmospheric transport. In the TTL, the inferred $\mathrm{Br}_{y}{ }^{\text {inorg }}$ is found to increase from a mean of $2.63 \pm 1.04 \mathrm{ppt}$ for $\theta$ in the range of $350-360 \mathrm{~K}$ to $5.11 \pm 1.57 \mathrm{ppt}$ for $\theta=390-400 \mathrm{~K}$, whereas in the subtropical LS it reaches $7.66 \pm 2.95 \mathrm{ppt}$ for $\theta \mathrm{s}$ in the range of 390 $400 \mathrm{~K}$. The non-negligible $\mathrm{Br}_{y}^{\text {inorg }}$ found for the lowest altitudes of the TTL, i.e., $2.63 \pm 1.04 \mathrm{ppt}$ with a range from 0.5 to $5.25 \mathrm{ppt}$ (or close to $0 \%$ up to $25 \%$ of all TTL bromine) is also remarkable. This may indicate a sizable but rather variable influx of inorganic bromine into the TTL, largely depending on the air mass history, i.e., source region, and atmospheric transport and processing.

Our findings on LS and TTL $\mathrm{Br}_{y}^{\text {inorg }}$ are in broad agreement with past experimental and theoretical studies on the processes and the amount of bromine injected by source gas and product gases into the TTL and eventually into the extratropical lowermost stratosphere (Ko et al., 1997; Schauffler et al., 1998; Wamsley et al., 1998; Dvortsov et al., 1999; Pfeilsticker et al., 2000; Montzka et al., 2003; Salawitch, 2006; Sinnhuber and Folkins, 2006; Hendrick et al., 2007; Laube et al., 2008; Dorf et al., 2006b, 2008; Sinnhuber et al., 2009; Salawitch et al., 2010; Schofield et al., 2011; Aschmann et al., 2011; Hossaini et al., 2012b; Ashfold et al., 2012; Hossaini et al., 2012a; Aschmann and Sinnhuber, 2013; Sala et al., 2014; Wang et al., 2015; Liang et al., 2014; WMO, 2014; Navarro et al., 2015, and many others). Our study, however, sets tighter limits than previous ones existing on the amount of $\mathrm{Br}_{y}^{\text {inorg }}$ and $\mathrm{Br}_{y}^{\text {org }}$, the influx of brominated source and product gases, and the photochemistry of bromine in the TTL and LS.

In particular, our study (re-)emphasizes that (a) variable amounts of VSLS bromine and (b) non-negligible amounts of $\mathrm{Br}_{y}^{\text {inorg }}$ are also transported into the TTL. While process (a) may strongly depend on the source region and season (Hossaini et al., 2016), process (b) may depend on the efficiency of heterogeneous processing and the removal of some $\mathrm{Br}_{y}^{\text {inorg }}$ by atmospheric (ice) clouds and aerosols (e.g., Aschmann et al., 2011; Aschmann and Sinnhuber, 2013). Therefore, it is not surprising that $\mathrm{TTL} \mathrm{Br}_{y}$ is rather variable (i.e., 20.3 to $22.3 \mathrm{ppt}$ ) in the season studied.

We also note that the amount of $\mathrm{Br}_{y}$ over the eastern $\mathrm{Pa}$ cific during the convective season assessed here and in the study of Navarro et al. (2015) is somewhat (up to 2 ppt) larger than that presently found on average in the stratosphere (e.g., 
Dorf et al., 2006b; Hendrick et al., 2007; Dorf et al., 2008; WMO, 2014). By assuming that this gap is significant, additional processes may come into the focus of stratospheric bromine research, i.e., the seasonality and possibly long-term trend of the bromine transported into the stratosphere (e.g., Levine et al., 2008; Krüger et al., 2008; Fueglistaler et al., 2009; Schofield et al., 2011; Ploeger et al., 2011).

It is conceivable that adding some inorganic bromine (from contribution 4) to TTL bromine would exert an additional impact on ozone. For the eastern Pacific $\left(170-90^{\circ} \mathrm{W}\right)$, our model-based assessment indicates a net loss of ozone of $-0.3 \mathrm{ppbv}^{-1} \mathrm{y}^{-1}$ at the base of the TTL $(\theta=355 \mathrm{~K})$ and a net production of +1.8 ppbv day $^{-1}$ in the upper part $(\theta=383 \mathrm{~K})$. Within the catalytic ozone loss cycles in the TTL (see Appendix Sect. A), the model indicates that those containing bromine contribute between $12 \%$ (at the base of the TTL) and $22 \%$ (at the top of the TTL) of the total.

\section{Data availability}

The data are available at https://espoarchive.nasa.gov/ archive/browse/attrex/id2/GHawk. 


\section{Appendix A: Ozone loss calculation}

The TOMCAT/SLIMCAT CTM contains a detailed description of stratospheric ozone chemistry, including radical and reservoir species in the odd-oxygen, odd-hydrogen, oddnitrogen, chlorine and bromine families. The model solves for the full odd-oxygen $\left(\mathrm{O}_{x}=\mathrm{O}_{3}+\mathrm{O}\left({ }^{3} \mathrm{P}\right)+\mathrm{O}\left({ }^{1} \mathrm{D}\right)\right)$ continuity equation based on the relevant reactions involving the $\mathrm{O}_{x}$ species. However, in order to ascribe chemical ozone loss to particular catalytic cycles, it is useful to transform the oddoxygen continuity equation, using steady-state assumptions, so that loss terms can be associated with the rate-determining steps of identifiable cycles. The methodology to achieve this was outlined by Johnston and Podolske (1978).

In this study the modeled chemical ozone (or $\mathrm{O}_{x}$ ) changes are related to catalytic cycles using this methodology applied to the full chemical scheme and results are given in Sect. 4.7. In this appendix, we describe this analysis for bromine (and some odd-hydrogen) chemistry and show how the catalytic cycles are identified. An approach such as this is necessary in order to avoid overestimation ("double-counting") or underestimation of ozone loss, which could occur if catalytic cycles are extracted in isolation from the rest of the model chemistry scheme.

Based on the subset of the TOMCAT/SLIMCAT reactions listed in Table 1, the odd-oxygen continuity (Eq. A1) would be written as

$$
\begin{aligned}
\frac{\mathrm{d}\left[\mathrm{O}_{x}\right]}{\mathrm{d} t} & =-k_{8} \cdot[\mathrm{OH}] \cdot[\mathrm{O}]-k_{10} \cdot\left[\mathrm{HO}_{2}\right] \cdot[\mathrm{O}] \\
& -k_{11} \cdot[\mathrm{OH}] \cdot\left[\mathrm{O}_{3}\right]-k_{12} \cdot[\mathrm{H}] \cdot\left[\mathrm{O}_{3}\right] \\
& -k_{36} \cdot\left[\mathrm{HO} \mathrm{H}_{2}\right] \cdot\left[\mathrm{O}_{3}\right]-k_{120} \cdot[\mathrm{Br}] \cdot\left[\mathrm{O}_{3}\right] \\
& -k_{121} \cdot[\mathrm{BrO}] \cdot[\mathrm{O}]-k_{137} \cdot[\mathrm{HBr}] \cdot\left[\mathrm{O}\left({ }^{1 \mathrm{D}}\right)\right] \\
& -k_{139} \cdot[\mathrm{HBr}] \cdot[\mathrm{O}]-k_{145} \cdot[\mathrm{BrONO} 2] \cdot[\mathrm{O}] \\
& +J_{\mathrm{BrO}} \cdot[\mathrm{BrO}] .
\end{aligned}
$$

This equation can be modified by assuming that shortlived species are in steady state. Based on the above reaction scheme, we can put $\mathrm{Br}$ in steady state to get the following:

$$
\begin{aligned}
\frac{\mathrm{d}[\mathrm{Br}]}{\mathrm{d} t} & =-k_{120} \cdot[\mathrm{Br}] \cdot\left[\mathrm{O}_{3}\right] \\
& +k_{121} \cdot[\mathrm{BrO}] \cdot[\mathrm{O}]+k_{123} \cdot[\mathrm{BrO}] \cdot[\mathrm{NO}] \\
& +k_{124} \cdot[\mathrm{BrO}] \cdot[\mathrm{OH}]+k_{125 a} \cdot[\mathrm{BrO}] \cdot[\mathrm{ClO}] \\
& +k_{125 b} \cdot[\mathrm{BrO}] \cdot[\mathrm{ClO}]+k_{127} \cdot[\mathrm{BrO}] \cdot[\mathrm{BrO}] \\
& -k_{134} \cdot[\mathrm{Br}] \cdot\left[\mathrm{CH}_{2} \mathrm{O}\right]-k_{135} \cdot[\mathrm{Br}] \cdot\left[\mathrm{HO}_{2}\right] \\
& +k_{136} \cdot[\mathrm{OH}] \cdot[\mathrm{HBr}]+k_{137} \cdot\left[\mathrm{O}\left({ }^{1 \mathrm{D}}\right)\right] \cdot[\mathrm{HBr}] \\
& +k_{139} \cdot[\mathrm{O}] \cdot[\mathrm{HBr}]+k_{146} \cdot[\mathrm{Br}] \cdot[\mathrm{BrONO} 2] \\
& +k_{147} \cdot[\mathrm{HBr}] \cdot[\mathrm{Cl}]+J_{\mathrm{BrO}} \cdot[\mathrm{BrO}] \\
& +J_{\mathrm{BrONO}_{2}} \cdot\left[\mathrm{BrONO}{ }_{2}\right]+J_{\mathrm{BrCl}} \cdot[\mathrm{BrCl}] \\
& +J_{\mathrm{HOBr}} \cdot[\mathrm{HOBr}]=0 .
\end{aligned}
$$

We can derive similar equations for many other short-lived species. Johnston and Podolske (1978) also discussed placing the rate of change in longer-lived species to zero in order to help simplify the odd-oxygen continuity equation. In practice the magnitude of these terms for odd-oxygen loss would be very small. Using steady-state expressions of $\mathrm{Br}, \mathrm{BrONO}_{2}$, $\mathrm{HBr}, \mathrm{Cl}, \mathrm{NO}_{2}, \mathrm{OClO}, \mathrm{OH}, \mathrm{HCl}$, and $\mathrm{H}_{2} \mathrm{O}$, Eq. (A1) can be converted to

$$
\begin{aligned}
\frac{\mathrm{d}[\mathrm{Br}]}{\mathrm{d} t} & =-k_{120} \cdot[\mathrm{Br}] \cdot\left[\mathrm{O}_{3}\right]+k_{121} \cdot[\mathrm{BrO}] \cdot[\mathrm{O}] \\
& +k_{123} \cdot[\mathrm{BrO}] \cdot[\mathrm{NO}]+k_{124} \cdot[\mathrm{BrO}] \cdot[\mathrm{OH}] \\
& +k_{125 a} \cdot[\mathrm{BrO}] \cdot[\mathrm{ClO}]+k_{125 b} \cdot[\mathrm{BrO}] \cdot[\mathrm{ClO}] \\
& +k_{127} \cdot[\mathrm{BrO}] \cdot[\mathrm{BrO}]-k_{134} \cdot[\mathrm{Br}] \cdot\left[\mathrm{CH}{ }_{2} \mathrm{O}\right] \\
& -k_{135} \cdot[\mathrm{Br}] \cdot\left[\mathrm{HO}_{2}\right]+k_{136} \cdot[\mathrm{OH}] \cdot[\mathrm{HBr}] \\
& +k_{137} \cdot\left[\mathrm{O}^{1} \mathrm{D}\right] \cdot[\mathrm{HBr}]+k_{139} \cdot[\mathrm{O}] \cdot[\mathrm{HBr}] \\
& +k_{146} \cdot[\mathrm{Br}] \cdot[\mathrm{BrONO} 2]+k_{147} \cdot[\mathrm{HBr}] \cdot[\mathrm{Cl}] \\
& +J_{\mathrm{BrO}} \cdot[\mathrm{BrO}]+J_{\mathrm{BrONO}_{2}} \cdot[\mathrm{BrONO}] \\
& +J_{\mathrm{BrCl}} \cdot[\mathrm{BrCl}]+J_{\mathrm{HOBr}} \cdot[\mathrm{HOBr}]=0 .
\end{aligned}
$$

This is part of the transformed odd-oxygen continuity equation as used in the diagnosis of the full TOMCAT/SLIMCAT chemistry scheme. For the chemical scheme given in Table 1, this equation can be further simplified by applying the steady-state approximation to $\mathrm{HOBr}$ $\left(\mathrm{d}\left[\mathrm{H}_{2} \mathrm{O}_{2}\right] / \mathrm{d} t=0\right)$ and $\mathrm{H}_{2} \mathrm{O}_{2}(\mathrm{~d}[\mathrm{HOBr}] / \mathrm{d} t=0)$ to get 
Table A1. TOMCAT/SLIMCAT reactions involving $\mathrm{Br}_{y}$ radical and reservoir species along with other reactions involving $\mathrm{HO}_{x}$ species. The numbering scheme follows that used in the model. Here $\mathrm{O}$ means $\mathrm{O}\left({ }^{3} \mathrm{P}\right)$.

\begin{tabular}{|c|c|}
\hline 8 & $\mathrm{OH}+\mathrm{O} \rightarrow \mathrm{H}+\mathrm{O}_{2}$ \\
\hline 9 & $\mathrm{O}_{2}+\mathrm{H}+\mathrm{M} \rightarrow \mathrm{HO}_{2}+\mathrm{M}$ \\
\hline 10 & $\mathrm{HO}_{2}+\mathrm{O} \rightarrow \mathrm{OH}+\mathrm{O}_{2}$ \\
\hline 11 & $\mathrm{OH}+\mathrm{O}_{3} \rightarrow \mathrm{HO}_{2}+\mathrm{O}_{2}$ \\
\hline 12 & $\mathrm{H}+\mathrm{O}_{3} \rightarrow \mathrm{OH}+\mathrm{O}_{2}$ \\
\hline $14 b$ & $\mathrm{OH}+\mathrm{OH} \rightarrow \mathrm{H}_{2} \mathrm{O}_{2}$ \\
\hline $15 \mathrm{a}$ & $\mathrm{H}+\mathrm{HO}_{2} \rightarrow \mathrm{OH}+\mathrm{OH}$ \\
\hline $15 b$ & $\mathrm{H}+\mathrm{HO}_{2} \rightarrow \mathrm{H}_{2}+\mathrm{O}_{2}$ \\
\hline 24 & $\mathrm{HO}_{2}+\mathrm{HO}_{2} \rightarrow \mathrm{H}_{2} \mathrm{O}_{2}+\mathrm{O}_{2}$ \\
\hline 36 & $\mathrm{HO}_{2}+\mathrm{O}_{3} \rightarrow \mathrm{OH}+2 \mathrm{O}_{2}$ \\
\hline 120 & $\mathrm{Br}+\mathrm{O}_{3} \rightarrow \mathrm{BrO}+\mathrm{O}_{2}$ \\
\hline 121 & $\mathrm{BrO}+\mathrm{O} \rightarrow \mathrm{Br}+\mathrm{O}_{2}$ \\
\hline 123 & $\mathrm{BrO}+\mathrm{NO} \rightarrow \mathrm{Br}+\mathrm{NO}_{2}$ \\
\hline 124 & $\mathrm{BrO}+\mathrm{OH} \rightarrow \mathrm{Br}+\mathrm{HO}_{2}$ \\
\hline $125 \mathrm{a}$ & $\mathrm{BrO}+\mathrm{ClO} \rightarrow \mathrm{Br}+\mathrm{OClO}$ \\
\hline $125 b$ & $\mathrm{BrO}+\mathrm{ClO} \rightarrow \mathrm{Br}+\mathrm{Cl}+\mathrm{O}_{2}$ \\
\hline $125 \mathrm{c}$ & $\mathrm{BrO}+\mathrm{ClO} \rightarrow \mathrm{BrCl}+\mathrm{O}_{2}$ \\
\hline 127 & $\mathrm{BrO}+\mathrm{BrO} \rightarrow \mathrm{Br}+\mathrm{Br}+\mathrm{O}_{2}$ \\
\hline 128 & $\mathrm{BrO}+\mathrm{NO}_{2}+\mathrm{M} \rightarrow \mathrm{BrONO}_{2}+\mathrm{M}$ \\
\hline 130 & $\mathrm{BrO}+\mathrm{HO}_{2} \rightarrow \mathrm{HOBr}+\mathrm{O}_{2}$ \\
\hline 131 & $\mathrm{O}+\mathrm{HOBr} \rightarrow \mathrm{OH}+\mathrm{BrO}$ \\
\hline 134 & $\mathrm{Br}+\mathrm{CH}_{2} \mathrm{O} \rightarrow \mathrm{HBr}+\mathrm{CHO}$ \\
\hline 135 & $\mathrm{Br}+\mathrm{HO}_{2} \rightarrow \mathrm{HBr}+\mathrm{O}_{2}$ \\
\hline 136 & $\mathrm{HBr}+\mathrm{OH} \rightarrow \mathrm{Br}+\mathrm{H}_{2} \mathrm{O}$ \\
\hline 137 & $\mathrm{HBr}+\mathrm{O}\left({ }^{1} \mathrm{D}\right) \rightarrow \mathrm{Br}+\mathrm{OH}$ \\
\hline 139 & $\mathrm{HBr}+\mathrm{O} \rightarrow \mathrm{Br}+\mathrm{OH}$ \\
\hline 145 & $\mathrm{BrONO}_{2}+\mathrm{O} \rightarrow \mathrm{BrO}+\mathrm{NO}_{3}$ \\
\hline 146 & $\mathrm{BrONO}_{2}+\mathrm{Br} \rightarrow \mathrm{Br}+\mathrm{Br}+\mathrm{NO}_{3}$ \\
\hline 147 & $\mathrm{HBr}+\mathrm{Cl} \rightarrow \mathrm{Br}+\mathrm{HCl}$ \\
\hline $\mathrm{J}_{\mathrm{BrO}}$ & $\mathrm{BrO}+\mathrm{h} v \rightarrow \mathrm{Br}+\mathrm{O}$ \\
\hline $\mathrm{J}_{\mathrm{BrONO} 2}$ & $\mathrm{BrONO}_{2}+\mathrm{h} v \rightarrow \mathrm{Br}+\mathrm{NO}_{3}$ \\
\hline $\mathrm{J}_{\mathrm{BrCl}}$ & $\mathrm{BrCl}+\mathrm{h} v \rightarrow \mathrm{Br}+\mathrm{Cl}$ \\
\hline $\mathrm{J}_{\mathrm{HOBr}}$ & $\mathrm{HOBr}+\mathrm{h} v \rightarrow \mathrm{Br}+\mathrm{OH}$ \\
\hline $\mathrm{J}_{\mathrm{H} 2 \mathrm{O} 2}$ & $\mathrm{H}_{2} \mathrm{O}_{2}+\mathrm{h} v \rightarrow 2 \mathrm{OH}$ \\
\hline
\end{tabular}

$$
\begin{aligned}
\frac{\mathrm{d}\left[\mathrm{O}_{x}\right]}{\mathrm{d} t} & =-2 \cdot k_{10} \cdot\left[\mathrm{HO}_{2}\right] \cdot[\mathrm{O}]-2 \cdot k_{12} \cdot[\mathrm{H}] \cdot\left[\mathrm{O}_{3}\right] \\
& -2 \cdot k_{15 a} \cdot[\mathrm{H}] \cdot\left[\mathrm{HO}_{2}\right]-2 \cdot k_{24} \cdot\left[\mathrm{HO}_{2}\right] \cdot\left[\mathrm{HO}_{2}\right] \\
& -2 \cdot k_{36} \cdot\left[\mathrm{HO}_{2}\right] \cdot\left[\mathrm{O}_{3}\right]-2 \cdot k_{121} \cdot[\mathrm{BrO}] \cdot[\mathrm{O}] \\
& -2 \cdot k_{125 b} \cdot[\mathrm{BrO}] \cdot[\mathrm{ClO}]-2 \cdot k_{127} \cdot[\mathrm{BrO}] \cdot[\mathrm{BrO}] \\
& -2 \cdot k_{130} \cdot[\mathrm{BrO}] \cdot\left[\mathrm{HO}_{2}\right]-2 \cdot k_{137} \cdot[\mathrm{HBr}] \cdot\left[\mathrm{O}\left({ }^{1} \mathrm{D}\right)\right] \\
& -2 \cdot k_{139} \cdot[\mathrm{HBr}] \cdot[\mathrm{O}]-2 \cdot J_{\mathrm{BrCl}} \cdot[\mathrm{BrCl}] .
\end{aligned}
$$

As discussed in Sect. 4.7, the dominant terms for ozone loss due to bromine chemistry are those involving the formation of $\mathrm{HOBr}\left(2 \cdot k_{130} \cdot[\mathrm{BrO}] \cdot\left[\mathrm{HO}_{2}\right]\right)$. Overall, the $\mathrm{HO}_{x}$ cycle represented by $2 \cdot k_{36} \cdot\left[\mathrm{HO}_{2}\right] \cdot\left[\mathrm{O}_{3}\right]$ dominates the ozone loss with a minor contribution from reactions involving $\mathrm{H}_{2} \mathrm{O}_{2}$ production $\left(2 \cdot k_{24} \cdot\left[\mathrm{HO}_{2}\right] \cdot\left[\mathrm{HO}_{2}\right]\right)$. 
Competing interests. The authors declare that they have no conflict of interest.

Acknowledgements. This study was funded through the NASA Upper Atmosphere Research Program (NASA ATTREX Grant numbers NNX10AO82A for HUPCRS, NNX10AO83A for GWAS, and NNX10AO80A for the mini-DOAS measurements). The NOAA ozone photometer and UCATS measurements were supported by the NASA ATTREX interagency agreement numbers NNA11AA54I and NNA11AA55I, respectively. Additional support for the mini-DOAS measurements came through the Deutsche Forschungsgemeinschaft, DFG (through grants PF-384 5-1/2, PF384 7-1/2 PF384 9-1/2, and PF384 12-1), and the EU project SHIVA (FP7-ENV-2007-1-226224). RuShan Gao, T. D. Thornberry, and D. W. Fahey were supported by the NOAA Atmospheric Composition and Climate Program and the NASA Radiation Sciences Program. The TOMCAT/SLIMCAT modeling was supported by the NERC National Centre for Atmospheric Science (NCAS), UK, and by the NERC TropHal project (NE/J02449X/1). M. P. Chipperfield was supported by a Royal Society Wolfson Merit Award. We thank Eric Jensen (NASA Ames Research Center, Moffett Field, California) and his team for coordinating the NASA-ATTREX mission. We thank Joe McNorton for help with the NOAA and AGAGE $\mathrm{CH}_{4}$ data. E. Atlas and M. Navarro gratefully acknowledge R. Lueb, R. Hendershot, and S. Gabbard for technical support in the field and X. Zhu and L. Pope for GWAS data analysis. Jim Elkins of NOAA would like to acknowledge the assistance of G. S. Dutton, J. D. Nance, and B. D. Hall during the ATTREX flights, calibration, and integration. The authors are grateful for the comments given by two anonymous reviewers, and the comments of Barbara Dix and Rainer Volkamer (CU, Boulder, USA).

Edited by: J. Ma

Reviewed by: two anonymous referees

\section{References}

Aschmann, J. and Sinnhuber, B.-M.: Contribution of very shortlived substances to stratospheric bromine loading: uncertainties and constraints, Atmos. Chem. Phys., 13, 1203-1219, doi:10.5194/acp-13-1203-2013, 2013.

Aschmann, J., Sinnhuber, B.-M., Atlas, E. L., and Schauffler, S. M.: Modeling the transport of very short-lived substances into the tropical upper troposphere and lower stratosphere, Atmos. Chem. Phys., 9, 9237-9247, doi:10.5194/acp-9-9237-2009, 2009.

Aschmann, J., Sinnhuber, B.-M., Chipperfield, M. P., and Hossaini, R.: Impact of deep convection and dehydration on bromine loading in the upper troposphere and lower stratosphere, Atmos. Chem. Phys., 11, 2671-2687, doi:10.5194/acp-11-2671-2011, 2011.

Ashfold, M. J., Harris, N. R. P., Atlas, E. L., Manning, A. J., and Pyle, J. A.: Transport of short-lived species into the Tropical Tropopause Layer, Atmos. Chem. Phys., 12, 6309-6322, doi:10.5194/acp-12-6309-2012, 2012.

Brinckmann, S., Engel, A., Bönisch, H., Quack, B., and Atlas, E.: Short-lived brominated hydrocarbons -observations in the source regions and the tropical tropopause layer, Atmos. Chem. Phys., 12, 1213-1228, doi:10.5194/acp-12-1213-2012, 2012.

Butz, A., Bösch, H., Camy-Peyret, C., Chipperfield, M. P., Dorf, M., Kreycy, S., Kritten, L., Prados-Román, C., Schwärzle, J., and Pfeilsticker, K.: Constraints on inorganic gaseous iodine in the tropical upper troposphere and stratosphere inferred from balloon-borne solar occultation observations, Atmos. Chem. Phys., 9, 7229-7242, doi:10.5194/acp-9-7229-2009, 2009.

Chen, H., Karion, A., Rella, C. W., Winderlich, J., Gerbig, C., Filges, A., Newberger, T., Sweeney, C., and Tans, P. P.: Accurate measurements of carbon monoxide in humid air using the cavity ring-down spectroscopy (CRDS) technique, Atmos. Meas. Tech., 6, 1031-1040, doi:10.5194/amt-6-1031-2013, 2013.

Chipperfield, M., Dhomse, S., Feng, W., McKenzie, R., Velders, G., and Pyle, J.: Quantifying the ozone and ultraviolet benefits already achieved by the Montreal Protocol, Nat. Commun., 6, 7233, doi:10.1029/96JD01167, 2015.

Chipperfield, M. P.: Multiannual simulations with a threedimensional chemical transport model, J. Geophys. Res., 104, 1781-1805, 1999.

Chipperfield, M. P.: New Version of the TOMCAT/SLIMCAT OffLine Chemical Transport Model: Intercomparison of Stratospheric Tracer Experiments, Q. J. Roy. Meteorol. Soc., 132, 1179-1203, doi:10.1256/qj.05.51, 2006.

Crosson, E. R.: A cavity ring-down analyzer for measurements of atmospheric levels of methane, carbon dioxide, and water vapor, Appl. Phys. B, 92, 403-408, 2008.

Daniel, J. S., Schauffler, S. M., Pollock, W. H., Solomon, S., Weaver, A., Heidt, L. E., Garcia, R. R., Atlas, E. L., and Vedder, J. F.: On the age of stratospheric air and inorganic chlorine and bromine release, J. Geophys. Res.-Atmos., 101, 16757-16770, doi:10.1029/96JD01167, 1996.

Dee, D. P., Uppala, S. M., Simmons, A. J., Berrisford, P., Poli, P., Kobayashi, S., Andrae, U., Balmaseda, M. A., Balsamo, G., Bauer, P., Bechtold, P., Beljaars, A. C. M., van de Berg, L., Bidlot, J., Bormann, N., Delsol, C., Dragani, R., Fuentes, M., Geer, A. J., Haimberger, L., Healy, S. B., Hersbach, H., Hólm, E. V., Isaksen, L., Kallberg, P., Köhler, M., Matricardi, M., McNally, A. P., Monge-Sanz, B. M., Morcrette, J.-J., Park, B.-K., Peubey, C., de Rosnay, P., Tavolato, C., Thepaut, J.-N., and Vitart, F.: The ERA-Interim reanalysis: configuration and performance of the data assimilation system, Q. J. Roy. Meteorol. Soc., 137, 553597, doi:10.1002/qj.828, 2011.

Deutschmann, T., Beirle, S., Frieß, U., Grzegorski, M., Kern, C., Kritten, L., Platt, U., Pukite, J., Wagner, T., Werner, B., and Pfeilsticker, K.: The Monte Carlo Atmospheric Radiative Transfer Model McArtim: Introduction and Validation of Jacobians and 3-D Features, J. Quant. Spectrosc. Ra., 112, 1119-1137, 2011.

Dlugokencky, E. J., Myers, R. C., Lang, P. M., Masarie, K. A., Crotwell, A. M., Thoning, K. W., Hall, B. D., Elkins, J. W., and Steele, L. P.: Conversion of NOAA atmospheric dry air $\mathrm{CH}_{4}$ mole fractions to a gravimetrically prepared standard scale, J. Geophys. Res.-Atmos., 110, D18306, doi:10.1029/2005JD006035, 2005.

Dorf, M., Bösch, H., Butz, A., Camy-Peyret, C., Chipperfield, M. P., Engel, A., Goutail, F., Grunow, K., Hendrick, F., Hrechanyy, S., Naujokat, B., Pommereau, J.-P., Van Roozendael, M., Sioris, C., Stroh, F., Weidner, F., and Pfeilsticker, K.: Balloonborne stratospheric $\mathrm{BrO}$ measurements: comparison with En- 
visat/SCIAMACHY BrO limb profiles, Atmos. Chem. Phys., 6, 2483-2501, doi:10.5194/acp-6-2483-2006, 2006a.

Dorf, M., Butler, J. H., Butz, A., Camy-Peyret, C., Chipperfield, M. P., Kritten, L., Montzka, S. A., Simmes, B., Weidner, F., and Pfeilsticker, K.: Long-term observations of stratospheric bromine reveal slow down in growth, Geophys. Res. Lett., 33, L24803, doi:10.1029/2006GL027714, 2006b.

Dorf, M., Butz, A., Camy-Peyret, C., Chipperfield, M. P., Kritten, L., and Pfeilsticker, K.: Bromine in the tropical troposphere and stratosphere as derived from balloon-borne $\mathrm{BrO}$ observations, Atmos. Chem. Phys., 8, 7265-7271, doi:10.5194/acp-8-72652008, 2008.

Dvortsov, V., Geller, M. A., Solomon, S., Schauffler, S. M., Atlas, E. L., and Blake, D. R.: Rethinking reactive halogen budget in the midlatitude stratosphere, Geophys. Res. Lett., 26, 1699-1702, 1999.

Elkins, J. W., Fahey, D. W., Gilligan, J. M., Dutton, G. S., Baring, T. J., Volk, C. M., Dunn, R. E., Myers, R. C., Montzka, S. A., Wamsley, P. R., Hayden, A. H., Butler, J. H., Thompson, T. M., Swanson, T. H., Dlugokencky, E. J., Novelli, P. C., Hurst, D. F., Lobert, J. M., Ciciora, S. J., McLaughlin, R. J., Thompson, T. L., Winkler, R. H., Fraser, P. J., Steele, L. P., and Lucarelli, M. P.: Airborne gas chromatograph for in situ measurements of longlived species in the upper troposphere and lower stratosphere, Geophys. Res. Lett., 23, 347-350, doi:10.1029/96GL00244, 1996.

Feng, W., Chipperfield, M. P., Dhomse, S., Monge-Sanz, B. M., Yang, X., Zhang, K., and Ramonet, M.: Evaluation of cloud convection and tracer transport in a three-dimensional chemical transport model, Atmos. Chem. Phys., 11, 5783-5803, doi:10.5194/acp-11-5783-2011, 2011.

Fernandez, R. P., Salawitch, R. J., Kinnison, D. E., Lamarque, J.-F., and Saiz-Lopez, A.: Bromine partitioning in the tropical tropopause layer: implications for stratospheric injection, Atmos. Chem. Phys., 14, 13391-13410, doi:10.5194/acp-1413391-2014, 2014.

Fernandez, R. P., Kinnison, D. E., Lamarque, J.-F., Tilmes, S., and Saiz-Lopez, A.: Impact of biogenic very short-lived bromine on the Antarctic ozone hole during the 21st century, Atmos. Chem. Phys. Discuss., doi:10.5194/acp-2016-840, in review, 2016.

Fitzenberger, R., Bösch, H., Camy-Peyret, C., Chpperfield, M., Harder, H., Platt, U., Pyle, J., Wagner, T., and Pfeilsticker, K.: First profile measurement of tropospheric BrO, Geophys. Res. Lett., 27, 2921-2924, 2000.

Fueglistaler, S., Dessler, A. E., Dunkerton, T. J., Folkins, I., Fu, Q., and Mote, P. W.: Tropical tropopause layer, Rev. Geophys., 47, RG1004, doi:10.1029/2008RG000267, 2009.

Gao, R. S., Ballard, J., Watts, L. A., Thornberry, T. D., Ciciora, S. J., McLaughlin, R. J., and Fahey, D. W.: A compact, fast UV photometer for measurement of ozone from research aircraft, Atmos. Meas. Tech., 5, 2201-2210, doi:10.5194/amt-5-2201-2012, 2012.

Harder, H., Bösch, H., Camy-Peyret, C., Chipperfield, M. P., Fitzenberger, R., Payan, S., Perner, D., Platt, U., Sinnhuber, B.M., and Pfeilsticker K.: Comparison of measured and modeled stratospheric BrO: Implications for the total amount of stratospheric bromine, Geophys. Res. Lett., 27, 3695-3698, doi:10.1029/1999GL011215, 2000.
Heidt, L. E., Vedder, J. F., Pollock, W. H., Lueb, R. A., and Henry, B. E.: Trace gases in the Antarctic atmosphere, J. Geophys. Res.Atmos., 94, 11599-11611, doi:10.1029/JD094iD09p11599, 1989.

Hendrick, F., Van Roozendael, M., Chipperfield, M. P., Dorf, M., Goutail, F., Yang, X., Fayt, C., Hermans, C., Pfeilsticker, K., Pommereau, J.-P., Pyle, J. A., Theys, N., and De Mazière, M.: Retrieval of stratospheric and tropospheric BrO profiles and columns using ground-based zenith-sky DOAS observations at Harestua, $60^{\circ} \mathrm{N}$, Atmos. Chem. Phys., 7, 4869-4885, doi:10.5194/acp-7-4869-2007, 2007.

Höpfner, M., Orphal, J., von Clarmann, T., Stiller, G., and Fischer, H.: Stratospheric $\mathrm{BrONO}_{2}$ observed by MIPAS, Atmos. Chem. Phys., 9, 1735-1746, doi:10.5194/acp-9-1735-2009, 2009.

Hossaini, R., Chipperfield, M. P., Dhomse, S., Ordóñez, C., Saiz-Lopez, A., Abraham, N. L., Archibald, A., Braesicke, P., Telford, P., Warwick, N., Yang, X., and Pyle, J.: Modelling future changes to the stratospheric source gas injection of biogenic bromocarbons, Geophys. Res. Lett., 39, L20813, doi:10.1029/2012GL053401, 2012a.

Hossaini, R., Chipperfield, M. P., Feng, W., Breider, T. J., Atlas, E., Montzka, S. A., Miller, B. R., Moore, F., and Elkins, J.: The contribution of natural and anthropogenic very short-lived species to stratospheric bromine, Atmos. Chem. Phys., 12, 371380, doi:10.5194/acp-12-371-2012, 2012b.

Hossaini, R., Mantle, H., Chipperfield, M. P., Montzka, S. A., Hamer, P., Ziska, F., Quack, B., Krüger, K., Tegtmeier, S., Atlas, E., Sala, S., Engel, A., Bönisch, H., Keber, T., Oram, D., Mills, G., Ordóñez, C., Saiz-Lopez, A., Warwick, N., Liang, Q., Feng, W., Moore, F., Miller, B. R., Marécal, V., Richards, N. A. D., Dorf, M., and Pfeilsticker, K.: Evaluating global emission inventories of biogenic bromocarbons, Atmos. Chem. Phys., 13, 11819-11838, doi:10.5194/acp-13-11819-2013, 2013.

Hossaini, R., Chipperfield, M. P., Montzka, S. A., Rap, A., Dhomse, S., and Feng, W.: Efficiency of short-lived halogens at influencing climate through depletion of stratospheric ozone, Nat. Geosci., 8, 186-190, doi:10.1038/ngeo2363, 2015.

Hossaini, R., Patra, P. K., Leeson, A. A., Krysztofiak, G., Abraham, N. L., Andrews, S. J., Archibald, A. T., Aschmann, J., Atlas, E. L., Belikov, D. A., Bönisch, H., Carpenter, L. J., Dhomse, S., Dorf, M., Engel, A., Feng, W., Fuhlbrügge, S., Griffiths, P. T., Harris, N. R. P., Hommel, R., Keber, T., Krüger, K., Lennartz, S. T., Maksyutov, S., Mantle, H., Mills, G. P., Miller, B., Montzka, S. A., Moore, F., Navarro, M. A., Oram, D. E., Pfeilsticker, K., Pyle, J. A., Quack, B., Robinson, A. D., Saikawa, E., Saiz-Lopez, A., Sala, S., Sinnhuber, B.-M., Taguchi, S., Tegtmeier, S., Lidster, R. T., Wilson, C., and Ziska, F.: A multi-model intercomparison of halogenated very short-lived substances (TransComVSLS): linking oceanic emissions and tropospheric transport for a reconciled estimate of the stratospheric source gas injection of bromine, Atmos. Chem. Phys., 16, 9163-9187, doi:10.5194/acp16-9163-2016, 2016.

Jensen, E.-J., Pfister, L., Jordan, D. E., Fahey, D. W., Newman, P. A., Thornberry, T., Rollins, A., Diskin, G., Bui, T. P., McGill, M., Hlavka, D., Lawson, R. P., Gao, R.-S., Pilewskie, P., Elkins, J., Hintsa, E., Moore, F., Mahoney, M. J., Atlas, E., Stutz, J., Pfeilsticker, K., Wofsy, S., Evan, S., and Rosenlof, K. H.: The NASA Airborne Tropical TRopopause EXperiment (ATTREX), SPARC 
newsletter, 41, 15-24, http://issuu.com/sparc-climate/docs/41_ sparcnewsletter_jul2013_web/24, 2013.

Jensen, E. J., Pfister, L., Jordan, D. E., Bui, T. V., Ueyama, R., Singh, H. B., Thornberry, T., Rollins, A. W., Gao, R.-S., Fahey, D. W., Rosenlof, K. H., Elkins, J. W., Diskin, G. S., DiGangi, J. P., Lawson, R. P., Woods, S., Atlas, E. L., Rodriguez, M. A. N., Wofsy, S. C., Pittman, J., Bardeen, C. G., Toon, O. B., Kindel, B. C., Newman, P. A., McGill, M. J., Hlavka, D. L., Lait, L. R., Schoeberl, M. R., Bergman, J. W., Selkirk, H. B., Alexander, M. J., Kim, J.-E., Lim, B. H., Stutz, J., and Pfeilsticker, K.: The NASA Airborne Tropical TRopopause EXperiment (ATTREX): High-Altitude Aircraft Measurements in the Tropical Western Pacific, B. Am. Meteorol. Soc., doi:10.1175/BAMS-D14-00263.1, 2015.

Johnston, H. S. and Podolske, J.: Interpretations of stratospheric photochemistry, Rev. Geophys., 16, 491-519, doi:10.1029/RG016i004p00491, 1978.

Ko, M., Sze, N., Scott, C., and Weisenstein, D.: On the relation between chlorine/bromine loading and short-lived tropospheric source gases, J. Geophys. Res., 102, 25507-25517, 1997.

Ko, M. K. W., Newman, P. A., Reimann, S., and Strahan, E.: Lifetimes of Stratospheric Ozone-Depleting Substances, Their Replacements, and Related Species, SPARC Report, WCRP15/2013, 1-255, 2013.

Kreycy, S., Camy-Peyret, C., Chipperfield, M. P., Dorf, M., Feng, W., Hossaini, R., Kritten, L., Werner, B., and Pfeilsticker, K.: Atmospheric test of the $\mathrm{J}\left(\mathrm{BrONO}_{2}\right) / \mathrm{k}_{\mathrm{BrO}}+\mathrm{NO}_{2}$ ratio: implications for total stratospheric $\mathrm{Br}_{y}$ and bromine-mediated ozone loss, Atmos. Chem. Phys., 13, 6263-6274, doi:10.5194/acp-136263-2013, 2013.

Kritten, L., Butz, A., Dorf, M., Deutschmann, T., Kühl, S., PradosRoman, C., Pukite, J., Rozanov, A., Schofield, R., and Pfeilsticker, K.: Time dependent profile retrieval of UV/vis absorbing radicals from balloon-borne limb measurements - a case study on $\mathrm{NO}_{2}$ and $\mathrm{O}_{3}$, Atmos. Meas. Tech., 3, 933-946, doi:10.5194/amt3-933-2010, 2010.

Kritten, L., Butz, A., Chipperfield, M. P., Dorf, M., Dhomse, S., Hossaini, R., Oelhaf, H., Prados-Roman, C., Wetzel, G., and Pfeilsticker, K.: Constraining the $\mathrm{N}_{2} \mathrm{O}_{5}$ UV absorption cross section from spectroscopic trace gas measurements in the tropical mid-stratosphere, Atmos. Chem. Phys., 14, 9555-9566, doi:10.5194/acp-14-9555-2014, 2014.

Krüger, K., Tegtmeier, S., and Rex, M.: Long-term climatology of air mass transport through the Tropical Tropopause Layer (TTL) during NH winter, Atmos. Chem. Phys., 8, 813-823, doi:10.5194/acp-8-813-2008, 2008.

Laube, J. C., Engel, A., Bönisch, H., Möbius, T., Worton, D. R., Sturges, W. T., Grunow, K., and Schmidt, U.: Contribution of very short-lived organic substances to stratospheric chlorine and bromine in the tropics -a case study, Atmos. Chem. Phys., 8, 7325-7334, doi:10.5194/acp-8-7325-2008, 2008.

Levine, J. G., Braesicke, P., Harris, N. R. P., and Pyle, J. A.: Seasonal and inter-annual variations in troposphere-to-stratosphere transport from the tropical tropopause layer, Atmos. Chem. Phys., 8, 3689-3703, doi:10.5194/acp-8-3689-2008, 2008.

Liang, Q., Atlas, E., Blake, D., Dorf, M., Pfeilsticker, K., and Schauffler, S.: Convective transport of very short lived bromocarbons to the stratosphere, Atmos. Chem. Phys., 14, 5781-5792, doi:10.5194/acp-14-5781-2014, 2014.
Mellouki, A., Talukdar, R.K., Schmoltner, A.-M., Gierczak, T., Mills, M. J., Solomon, S., and Ravishankara, A. R.: Atmospheric lifetimes and ozone depletion potentials of methyl bromide $\left(\mathrm{CH}_{3} \mathrm{Br}\right)$ and dibromomethane $\left(\mathrm{CH}_{2} \mathrm{Br}_{2}\right)$, Geophys. Res. Lett., 19, 2059-2062, 1992.

Michael, J. V., Lee, J. H., Payne, W. A., and Stief, L. J.: Absolute rate of reaction of bromine atoms with ozone from $200-360 \mathrm{~K}, \mathrm{~J}$. Atmos. Chem., 68, 4093-4097, 1978.

Michelsen, H. A., Manney, G. L., Gunson, M. R., Rinsland, C. P., and Zander, R.: Correlations of stratospheric abundances of $\mathrm{CH}_{4}$ and $\mathrm{N}_{2} \mathrm{O}$ derived from ATMOS measurements, Geophys. Res. Lett., 25, 2777-2780, doi:10.1029/98GL01977, 1998.

Montzka, S., Butler, J., Hall, B., Mondell, D., and Elkins, J.: A decline in tropospheric organic bromine, Geophys. Res. Lett., 30, 1826-1829, 2003.

Moore, F. L., Elkins, J. W., Ray, E. A., Dutton, G. S., Dunn, R. E., Fahey, D. W., McLaughlin, R. J., Thompson, T. L., Romashkin, P. A., Hurst, D. F., and Wamsley, P. R.: Balloonborne in situ gas chromatograph for measurements in the troposphere and stratosphere, J. Geophys. Res.-Atmos., 108, 8330, doi:10.1029/2001JD000891, 2003.

Navarro, M. A., Atlas, E. L., Saiz-Lopez, A., Rodriguez-Lloveras, X., Kinnison, D. E., Lamarque, J.-F., Tilmes, S., Filus, M., Harris, N. R. P., Meneguz, E., Ashfold, M. J., Manning, A. J., Cuevas, C. A., Schauffler, S. M., and Donets, V.: Airborne measurements of organic bromine compounds in the Pacific tropical tropopause layer, P. Natl. Acad. Sci. USA, 112, 13789-13793, doi:10.1073/pnas.1511463112, 2015.

Nicovich, J. M., Kreutter, K. D., and Wine, P. H.: Kinetics of the Reactions of $\left.\mathrm{Cl}^{2}{ }^{2} P_{j}\right)$ and $\operatorname{Br}\left({ }^{2} P_{3 / 2}\right)$ with $O_{3}$, Int. J. Chem. Kinet., 22, 399-414, 1990.

Orbe, C., Waugh, D. W., and Newman, P. A.: Air-mass origin in the tropical lower stratosphere: The influence of Asian boundary layer air, Geophys. Res. Lett., 42, 4240-4248, doi:10.1002/2015GL063937, 2015.

Parrella, J. P., Chance, K., Salawitch, R. J., Canty, T., Dorf, M., and Pfeilsticker, K.: New retrieval of BrO from SCIAMACHY limb: an estimate of the stratospheric bromine loading during April 2008, Atmos. Meas. Tech., 6, 2549-2561, doi:10.5194/amt-62549-2013, 2013.

Pfeilsticker, K., Sturges, W. T., Bösch, H., Camy-Peyret, C., Chipperfield, M. P., Engel, A., Fitzenberger, R., Müller, M., Payan, S., and Sinnhuber, B.-M.: Lower stratospheric organic and inorganic bromine budget for the Arctic winter 1998/99, Geophys. Res. Lett., 27, 3305-3308, doi:10.1029/2000GL011650, 2000.

Platt, U. and Stutz, J.: Differential Optical Absorption Spectroscopy (DOAS), Principle and Applications, ISBN 3-34021193-4, Springer Verlag, Heidelberg, 2008.

Ploeger, F., Fueglistaler, S., Grooß, J.-U., Günther, G., Konopka, P., Liu, Y. S., Müller, R., Ravegnani, F., Schiller, C., Ulanovski, A., and Riese, M.: Insight from ozone and water vapour on transport in the tropical tropopause layer (TTL), Atmos. Chem. Phys., 11, 407-419, doi:10.5194/acp-11-407-2011, 2011.

Proffitt, M. H. and McLaughlin, R. J.: Fast-response dual-beam UVabsorption ozone photometer suitable for use on stratospheric balloons, Rev. Sci. Instrum., 54, 1719-1728, 1983.

Raecke, R.: Atmospheric spectoscopy of trace gases and water vapour in the tropical tropopause layer from the NASA Global 
Hawk, Master thesis, Institut für Umweltphysik, Universität Heidelberg, 2013.

Ravishankara, A. R., Daniel, J., and W., P. R.: Nitrous Oxide $\left(\mathrm{N}_{2} \mathrm{O}\right)$ : The Dominant Ozone-Depleting Substance Emitted in the 21st Century, Science, 326, 123-125, 2009.

Rella, C. W., Chen, H., Andrews, A. E., Filges, A., Gerbig, C., Hatakka, J., Karion, A., Miles, N. L., Richardson, S. J., Steinbacher, M., Sweeney, C., Wastine, B., and Zellweger, C.: High accuracy measurements of dry mole fractions of carbon dioxide and methane in humid air, Atmos. Meas. Tech., 6, 837-860, doi:10.5194/amt-6-837-2013, 2013.

Richter, A., Wittrock, F., Ladstätter-Weiß enmayer, A., and Burrows, J.: GOME measurements of stratospheric and tropospheric BrO, Adv. Space Res., 29, 1667-1672, doi:10.1016/S02731177(02)00123-0, 2002.

Riese, M., Ploeger, F., Rap, A., Vogel, B., Konopka, P., Dameris, M., and Forster, P.: Impact of uncertainties in atmospheric mixing on simulated UTLS composition and related radiative effects, J. Geophys. Res.-Atmos., 117, D16305, doi:10.1029/2012JD017751, 2012.

Rodgers, C.: Inverse methods for atmospheric sounding, World Scientific, Singapore, New Jersey, London, Hongkong, 2000.

Rozanov, A., Kühl, S., Doicu, A., McLinden, C., Pukite, J., Bovensmann, H., Burrows, J. P., Deutschmann, T., Dorf, M., Goutail, F., Grunow, K., Hendrick, F., von Hobe, M., Hrechanyy, S., Lichtenberg, G., Pfeilsticker, K., Pommereau, J. P., Van Roozendael, M., Stroh, F., and Wagner, T.: BrO vertical distributions from SCIAMACHY limb measurements: comparison of algorithms and retrieval results, Atmos. Meas. Tech., 4, 1319-1359, doi:10.5194/amt-4-1319-2011, 2011.

Saiz-Lopez, A. and Fernandez, R. P.: On the formation of tropical rings of atomic halogens: Causes and implications, Geophys. Res. Lett., 43, GL067608, doi:10.1002/2015GL067608, 2016.

Saiz-Lopez, A., Plane, J. M. C., and Shillito, J. A.: Bromine oxide in the mid-latitude marine boundary layer, Geophys. Res. Lett., 31, L03111, doi:10.1029/2003GL018956, 2004.

Saiz-Lopez, A., Lamarque, J.-F., Kinnison, D. E., Tilmes, S., Ordóñez, C., Orlando, J. J., Conley, A. J., Plane, J. M. C., Mahajan, A. S., Sousa Santos, G., Atlas, E. L., Blake, D. R., Sander, S. P., Schauffler, S., Thompson, A. M., and Brasseur, G.: Estimating the climate significance of halogen-driven ozone loss in the tropical marine troposphere, Atmos. Chem. Phys., 12, 3939-3949, doi:10.5194/acp-12-3939-2012, 2012.

Sala, S., Bönisch, H., Keber, T., Oram, D. E., Mills, G., and Engel, A.: Deriving an atmospheric budget of total organic bromine using airborne in situ measurements from the western Pacific area during SHIVA, Atmos. Chem. Phys., 14, 6903-6923, doi:10.5194/acp-14-6903-2014, 2014

Salawitch, R.: Atmospheric chemistry: Biogenic bromine, Nature, 439, 275-277, 2006.

Salawitch, R. J., Canty, T., Kurosu, T., Chance, K., Liang, Q., da Silva, A., Pawson, S., Nielsen, J. E., Rodriguez, J. M., Bhartia, P. K., Liu, X., Huey, L. G., Liao, J., Stickel, R. E., Tanner, D. J., Dibb, J. E., Simpson, W. R., Donohoue, D., Weinheimer, A., Flocke, F., Knapp, D., Montzka, D., Neuman, J. A., Nowak, J. B., Ryerson, T. B., Oltmans, S., Blake, D. R., Atlas, E. L., Kinnison, D. E., Tilmes, S., Pan, L. L., Hendrick, F., Van Roozendael, M., Kreher, K., Johnston, P. V., Gao, R. S., Johnson, B., Bui, T. P., Chen, G., Pierce, R. B., Crawford, J. H., and Jacob, D. J.:
A new interpretation of total column BrO during Arctic spring, Geophys. Res. Lett., 37, L21805, doi:10.1029/2010GL043798, 2010.

Sander, S., Friedl, R. R., Barkern, J., Golden, D., Kurylo, M., Wine, P., Abbat, J., Burkholder, J., Moortgaret, C., Huie, R., and Orkin, R. E.: Chemical kinetics and photochemical data for use in atmospheric studies, Technical Report, NASA/JPL Publication, 17, 2011.

Schäfer, H., Fletcher, S. E. M., Veidt, C., Lassey, K. R., Brailsford, G. W., Bromley, T. M., Dlugokencky, E. J., Michel, S. E., Miller, J. B., Levin, I., Lowe, D. C., Martin, R. J., Vaughn, B. H., and White, J. W. C.: A 21st century shift from fossil-fuel to biogenic methane emissions indicated by ${ }^{13} \mathrm{CH}_{4}$, American Association for the Advancement of Science, doi:10.1126/science.aad2705, 2016.

Schauffler, S., Atlas, E., Blake, D., Flocke, F., Lueb, R., Lee-Taylor, J., Stroud, V., and Travnicek, W.: Distribution of brominated organic compounds in the upper troposphere and lower stratosphere, J. Geophys. Res., 104, 21513-21535, 1999.

Schauffler, S. M., Heidt, L. E., Pollock, W. H., Gilpin, T. M., Vedder, J. F., Solomon, S., Lueb, R. A., and Atlas, E. L.: Measurements of halogenated organic compounds near the tropical tropopause, Geophys. Res. Lett., 20, 2567-2570, doi:10.1029/93GL02840, 1993.

Schauffler, S. M., Atlas, E. L., Flocke, F., Lueb, R. A., Stroud, V., and Travnicek, W.: Measurement of bromine-containing organic compounds at the tropical tropopause, Geophys. Res. Lett., 25, 317-320, 1998.

Schmidt, J. A., Jacob, D. J., Horowitz, H. M., Hu, L., Sherwen, T., Evans, M. J., Liang, Q., Suleiman, R. M., Oram, D. E., Le Breton, M., Percival, C. J., Wang, S., Dix, B., and Volkamer, R.: Modeling the observed tropospheric BrO background: Importance of multiphase chemistry and implications for ozone, $\mathrm{OH}$, and mercury, J. Geophys. Res.-Atmos., 121, 11819-11835, doi:10.1002/2015JD024229, 2016.

Schofield, R., Fueglistaler, S., Wohltmann, I., and Rex, M.: Sensitivity of stratospheric $\mathrm{Br}_{y}$ to uncertainties in very short lived substance emissions and atmospheric transport, Atmos. Chem. Phys., 11, 1379-1392, doi:10.5194/acp-11-1379-2011, 2011.

Sinnhuber, B.-M. and Folkins, I.: Estimating the contribution of bromoform to stratospheric bromine and its relation to dehydration in the tropical tropopause layer, Atmos. Chem. Phys., 6, 4755-4761, doi:10.5194/acp-6-4755-2006, 2006.

Sinnhuber, B.-M., Sheode, N., Sinnhuber, M., Chipperfield, M. P., and Feng, W.: The contribution of anthropogenic bromine emissions to past stratospheric ozone trends: a modelling study, Atmos. Chem. Phys., 9, 2863-2871, doi:10.5194/acp-9-2863-2009, 2009.

Sioris, C. E., Kovalenko, L. J., McLinden, C. A., Salawitch, R. J., Van Roozendael, M., Goutail, F., Dorf, M., Pfeilsticker, K., Chance, K., von Savigny, C., Liu, X., Kurosu, T. P., Pommereau, J.-P., Bösch, H., and Frerick, J.: Latitudinal and vertical distribution of bromine monoxide in the lower stratosphere from Scanning Imaging Absorption Spectrometer for Atmospheric Chartography limb scattering measurements, J. Geophys. Res.Atmos., 111, D14301, doi:10.1029/2005JD006479, 2006.

Stachnik, R. A., Millán, L., Jarnot, R., Monroe, R., McLinden, C., Kühl, S., Pukite, J., Shiotani, M., Suzuki, M., Kasai, Y., Goutail, F., Pommereau, J. P., Dorf, M., and Pfeilsticker, K.: Strato- 
spheric BrO abundance measured by a balloon-borne submillimeterwave radiometer, Atmos. Chem. Phys., 13, 3307-3319, doi:10.5194/acp-13-3307-2013, 2013.

Sturges, W. T., Oram, D. E., Carpenter, L. J., Penkett, S. A., and Engel, A.: Bromoform as a source of stratospheric bromine, Geophys. Res. Lett., 27, 2081-2084, doi:10.1029/2000GL011444, 2000.

Stutz, J., Werner, B., Spolaor, M., Scalone, L., Festa, J., Tsai, C., Cheung, R., Colosimo, S., Tricoli, U., Raecke, R., Hossaini, R., Chipperfield, M., Feng, W., Gao, R.-S., Hintsa, E., Elkins, J., Moore, F., Daube, B., Pittman, J., Wofsy, S., and Pfeilsticker, K.: A New Differential Optical Absorption Spectroscopy Instrument to Study Atmospheric Chemistry from a High-Altitude Unmanned Aircraft, Atmos. Meas. Tech. Discuss., doi:10.5194/amt2016-251, in review, 2016.

Tegtmeier, S., Krüger, K., Quack, B., Atlas, E. L., Pisso, I., Stohl, A., and Yang, X.: Emission and transport of bromocarbons: from the West Pacific ocean into the stratosphere, Atmos. Chem. Phys., 12, 10633-10648, doi:10.5194/acp-12-10633-2012, 2012.

Theys, N., Van Roozendael, M., Errera, Q., Hendrick, F., Daerden, F., Chabrillat, S., Dorf, M., Pfeilsticker, K., Rozanov, A., Lotz, W., Burrows, J. P., Lambert, J.-C., Goutail, F., Roscoe, H. K., and De Mazière, M.: A global stratospheric bromine monoxide climatology based on the BASCOE chemical transport model, Atmos. Chem. Phys., 9, 831-848, doi:10.5194/acp-9-831-2009, 2009.

Theys, N., Van Roozendael, M., Hendrick, F., Yang, X., De Smedt, I., Richter, A., Begoin, M., Errera, Q., Johnston, P. V., Kreher, K., and De Mazière, M.: Global observations of tropospheric $\mathrm{BrO}$ columns using GOME-2 satellite data, Atmos. Chem. Phys., 11, 1791-1811, doi:10.5194/acp-11-1791-2011, 2011.

Van Roozendael, M., Wagner, T., Richter, A., Pundt, I., Arlander, D., Burrows, J., Chipperfield, M. P., Fayt, C., Johnston, P., Lambert, J., Kreher, K., Pfeilsticker, K., Platt, U., Pommereau, J. P., Sinnhuber, B., Tornkvist, K., and Wittrock, F.: Intercomparison of BrO Measurements from ERS-2 GOME, Ground-based and balloon platforms, Adv. Space. Res., 29, 1161-1666, 2002.

Volkamer, R., Baidar, S., Campos, T. L., Coburn, S., DiGangi, J. P., Dix, B., Eloranta, E. W., Koenig, T. K., Morley, B., Ortega, I., Pierce, B. R., Reeves, M., Sinreich, R., Wang, S., Zondlo, M. A., and Romashkin, P. A.: Aircraft measurements of BrO, IO, glyoxal, $\mathrm{NO}_{2}, \mathrm{H}_{2} \mathrm{O}, \mathrm{O}_{2}-\mathrm{O}_{2}$ and aerosol extinction profiles in the tropics: comparison with aircraft-/ship-based in situ and lidar measurements, Atmos. Meas. Tech., 8, 2121-2148, doi:10.5194/amt-8-2121-2015, 2015.

Wamsley, P. R., Elkins, J. W., Fahey, D. W., Dutton, G. S., Volk, C. M. Myers, R. C., Montzka, S. A., Butler, J. H., Clarke, A. D., Fraser, P. J., Steele, L. P., Lucarelli, M. P., Atlas, E. L., Schauffler, S. M., Blake, D. R., Rowland, F. S., Sturges, W. T., Lee, J. M., Penkett, S. A., Engel, A., Stimpfle, R. M., Chan, K. R., Weisenstein, D. K., Ko, M. K. W., and Salawitch, R. J.: Distribution of halon-1211 in the upper troposphere and lower stratosphere and the 1994 total bromine budget, J. Geophys. Res, 103, 1513-1526, 1998.

Wang, S., Schmidt, J. A., Baidar, S., Coburn, S., Dix, B., Koenig, T. K., Apel, E., Bowdalo, D., Campos, T. L., Eloranta, E., Evans, M. J., DiGangi, J. P., Zondlo, M. A., Gao, R.-S., Haggerty, J. A., Hall, S. R., Hornbrook, R. S., Jacob, D., Morley, B., Pierce, B., Reeves, M., Romashkin, P., ter Schure, A., and Volkamer, R.: Ac- tive and widespread halogen chemistry in the tropical and subtropical free troposphere, P. Natl. Acad. Sci. USA, 112, 92819286, doi:10.1073/pnas.1505142112, 2015.

Weidner, F., Bösch, H., Bovensmann, H., Burrows, J. P., Butz, A., Camy-Peyret, C., Dorf, M., Gerilowski, K., Gurlit, W., Platt, U., von Friedeburg, C., Wagner, T., and Pfeilsticker, K.: Balloonborne limb profiling of UV/vis skylight radiances, $\mathrm{O}_{3}, \mathrm{NO}_{2}$, and BrO: technical set-up and validation of the method, Atmos. Chem. Phys., 5, 1409-1422, doi:10.5194/acp-5-1409-2005, 2005.

Wisher, A., Oram, D. E., Laube, J. C., Mills, G. P., van Velthoven, P., Zahn, A., and Brenninkmeijer, C. A. M.: Very short-lived bromomethanes measured by the CARIBIC observatory over the North Atlantic, Africa and Southeast Asia during 2009-2013, Atmos. Chem. Phys., 14, 3557-3570, doi:10.5194/acp-14-35572014, 2014.

WMO: Scientific assessment of ozone depletion: 2010, Global Ozone Research and Monitoring Project, World Meteorological Organisation (WMO), Geneve, Switzerland, 52, 512 pp., 2011.

WMO: Scientific assessment of ozone depletion: 2014, Global Ozone Research and Monitoring Project, World Meteorological Organisation (WMO), Geneve, Switzerland, 55, 416 pp., 2014.

Wofsy, S. C., Daube, B., Jimenez, R., Kort, E., Pittman, J., Park, S., Commane, R., Xiang, B., Santoni, G. ans Jacob, D., Fisher, J., Pickett-Heaps, C., Wang, H., Wecht, K., Wang, Q.-Q., Stephens, B., Shertz, S., Romashkin, P., Campos, T., Haggerty, J., Cooper, W., Rogers, D., Beaton, S., Hendershot, R., Elkins, J. W., Fahey, D. W., Gao, F. R. S., Moore, F., Montzka, S. A., Schwarz, D. J. P., Miller, Hurst, B., Sweeney, C., Oltmans, S. J., Nance, D., Hintsa, E., Dutton, G., Watts, L. A., Spackman, J. R., Rosenlof, K. H., Ray, E. A., Zondlo, M., Diao, M., Keeling, R., Bent, J., Atlas, E., Lueb, R., Mahoney, M., Chahine, M., Olson, E., Patra, P., Ishijima, K., Engelen, R., Flemming, J., Nassar, R., Jones, D. B. A., and Mikaloff Fletcher, S. E.: HIAPER Pole-to-Pole Observations (HIPPO): fine-grained, global-scale measurements of climatically important atmospheric gases and aerosols, Philos. T. R. Soc. A, 369, 2073-2086, doi:10.1098/rsta.2010.0313, 2011.

Yokouchi, Y., Mukai, H., Yamamoto, H., Otsuki, A., Saitoh, C., and Nojiri, Y.: Distribution of methyl iodide, ethyl iodide, bromoform, and dibromomethane over the ocean (east and southeast Asian seas and the western Pacific), J. Geophys. Res., 102, 88058809, 1997.

Yokouchi, Y., Hasebe, F., Fujiwara, M., Takashima, H., Shiotani, M., Nishi, N., Kanaya, Y., Hashimoto, S., Fraser, P., ToomSauntry, D., Mukai, H., and Nojiri, Y.: Correlations and emission ratios among bromoform, dibromochloromethane, and dibromomethane in the atmosphere, J. Geophys. Res.-Atmos., 110, D23309, doi:10.1029/2005JD006303, 2005.

Ziska, F., Quack, B., Abrahamsson, K., Archer, S. D., Atlas, E., Bell, T., Butler, J. H., Carpenter, L. J., Jones, C. E., Harris, N. R. P., Hepach, H., Heumann, K. G., Hughes, C., Kuss, J., Krüger, K., Liss, P., Moore, R. M., Orlikowska, A., Raimund, S., Reeves, C. E., Reifenhäuser, W., Robinson, A. D., Schall, C., Tanhua, T., Tegtmeier, S., Turner, S., Wang, L., Wallace, D., Williams, J., Yamamoto, H., Yvon-Lewis, S., and Yokouchi, Y.: Global sea-toair flux climatology for bromoform, dibromomethane and methyl iodide, Atmos. Chem. Phys., 13, 8915-8934, doi:10.5194/acp13-8915-2013, 2013. 